\title{
※USGS
}

science for a changing world

Prepared in cooperation with the University of Arizona School of Natural Resources and the Environment, the Bureau of Land Management, and the U.S. Fish and Wildlife Service

\section{Effects of Drought and Fire on Bird Communities of the Kofa National Wildlife Refuge, Arizona

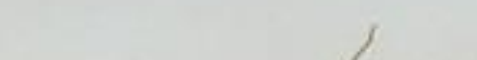

Open File Report 2015-1240
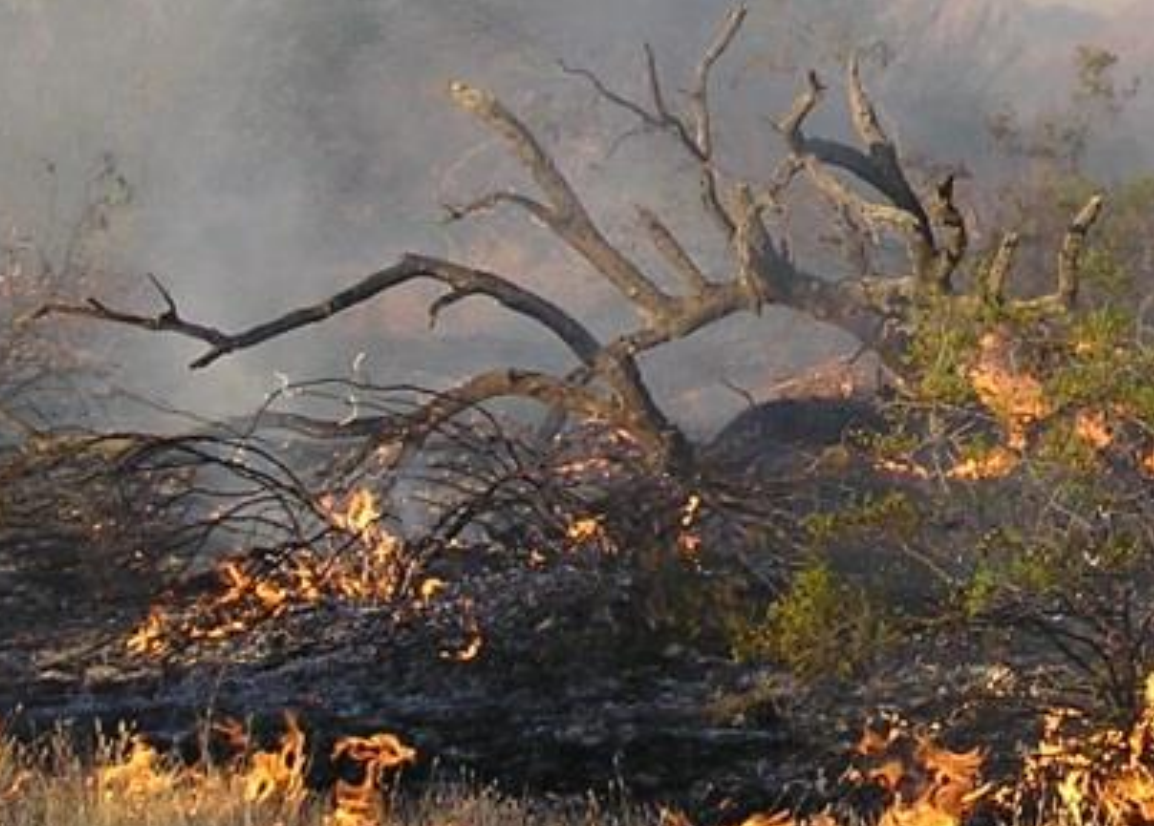

U,S: Department of the interior

U. S. Geological suryey

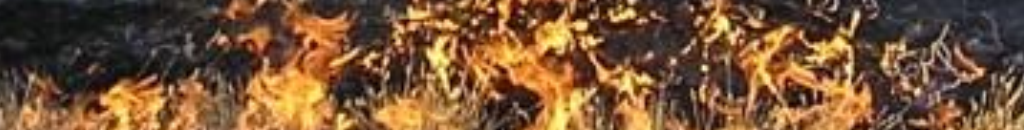


Cover

The King Valley Fire consumes a paloverde tree in the Kofa National Wildlife Refuge. In 2005, a human-caused, 9,000-hectare fire in the King Valley spread from the Yuma Proving Ground into the Kofa National Wildlife Refuge Arizona. More than 80 percent of xeroriparian live cover within the fire's perimeter was lost. Photo from the U.S. Fish and Wildife Service, 2005. 


\section{Effects of Drought and Fire on Bird Communities of the Kofa National Wildlife Refuge, Arizona}

By Chris McCreedy, Charles van Riper, III, Todd C. Esque, and Abigail J. Darrah

Open-File Report 2015-1240

U. S. Department of the Interior

U. S. Geological Survey 


\section{U.S. Department of the Interior \\ SALLY JEWELL, Secretary}

\section{U.S. Geological Survey \\ Suzette M. Kimball, Director}

U.S. Geological Survey, Reston, Virginia: 2015

For more information on the USGS—-the Federal source for science about the Earth, its natural and living resources, natural hazards, and the environment-visit http://www.usgs.gov or call 1-888-ASK-USGS

For an overview of USGS information products, including maps, imagery, and publications, visit http://www.usgs.gov/pubprod

To order this and other USGS information products, visit http://store.usgs.gov

Any use of trade, firm, or product names is for descriptive purposes only and does not imply endorsement by the U.S. Government.

Although this information product, for the most part, is in the public domain, it also may contain copyrighted materials as noted in the text. Permission to reproduce copyrighted items must be secured from the copyright owner.

Suggested citation:

McCreedy, C., van Riper, C., III, Esque, T.C., and Darrah, A.J., 2015, Effects of drought and fire on bird communities of the Kofa National Wildlife Refuge, Arizona: U.S. Geological Survey Open-File Report 2015-1240, 34 p., http://dx.doi.org/10.3133/ofr20151240.

ISSN 2331-1258 (online) 


\section{Contents}

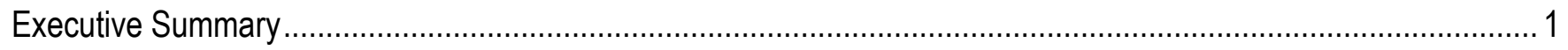

Chapter 1-Drought-Caused Delay in Breeding and Lowered Nesting Success of Sonoran Desert Birds ...... 2

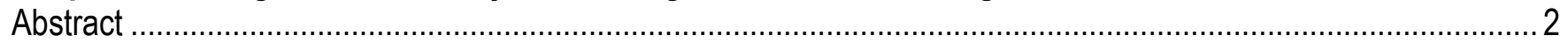

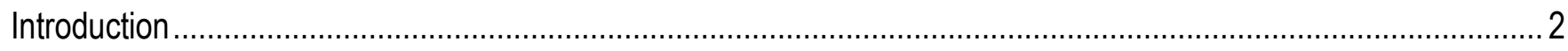

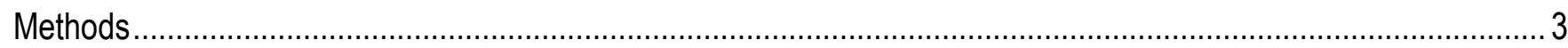

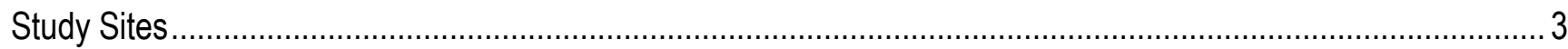

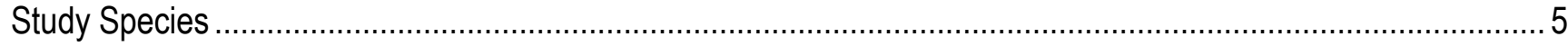

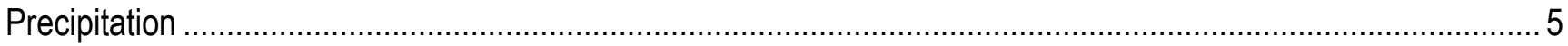

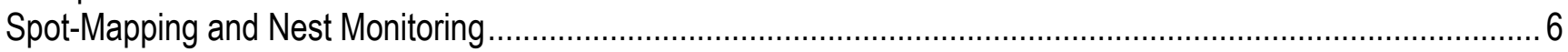

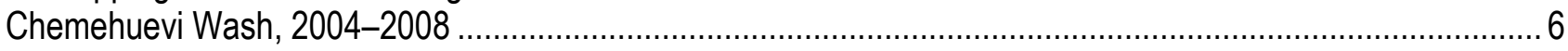

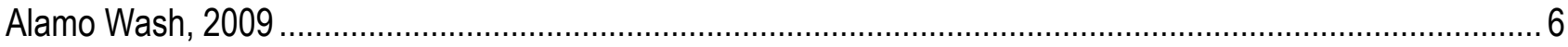

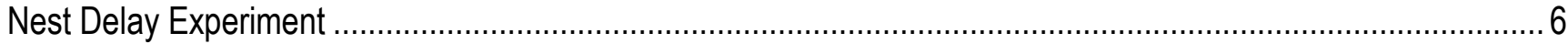

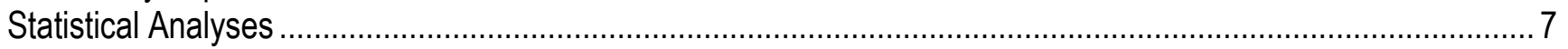

Nest Initiation Date, Mayfield Nest Survival, and Winter Season Rainfall...................................................

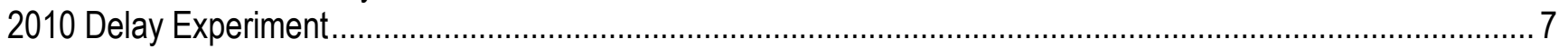

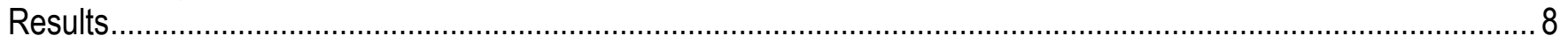

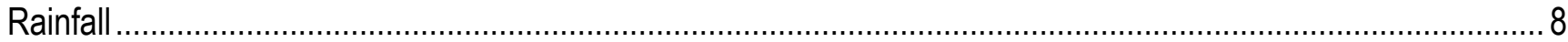

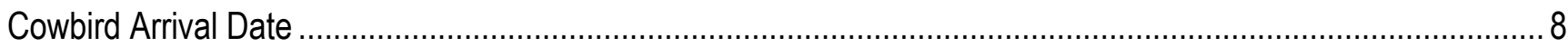

Winter Season Rainfall and Nest Initiation ........................................................................................... 9

Winter Season Rainfall and Mayfield Nest Survival ................................................................................ 10

Nest Delay Experiment, 2010: Comparison of Control and Delayed First-Clutch Attempts................................. 10

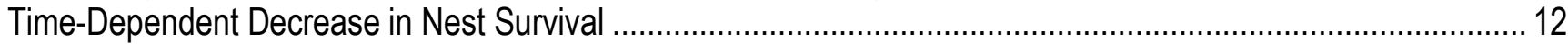

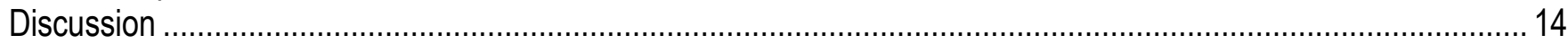

Climate Change Projections Suggest Delayed Phenology in the Sonoran Desert ........................................... 14

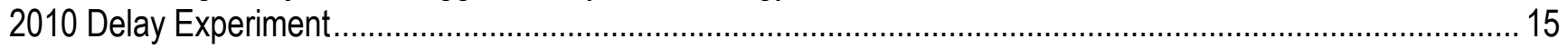

Factors Affecting Avian Reproductive Success During Drought............................................................... 16

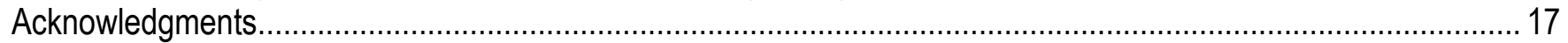

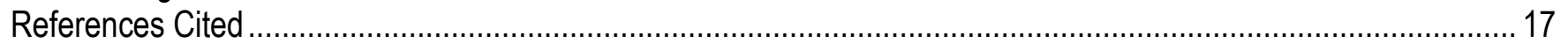

Chapter 2-Avian Response to Fire at Kofa National Wildlife Refuge in the Sonoran Desert ........................ 21

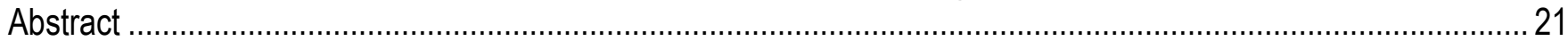

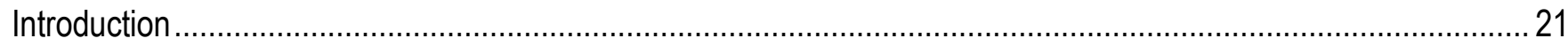

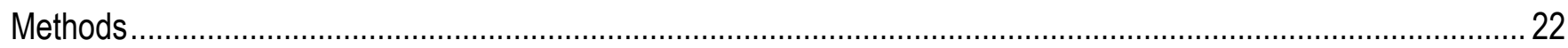

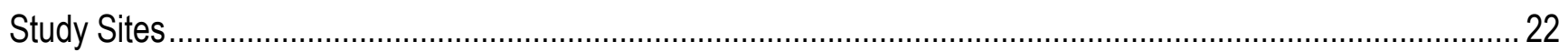

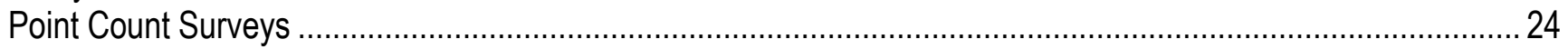

Point Count Vegetation Assessments at Burned and Unburned Points ..................................................... 25

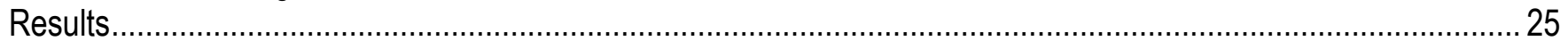

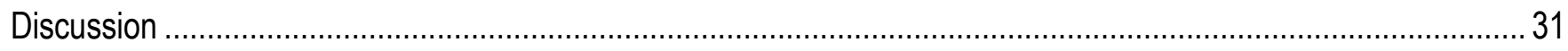

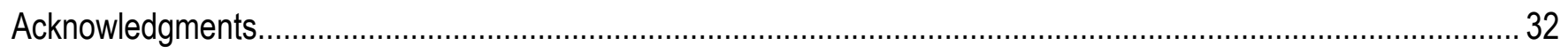

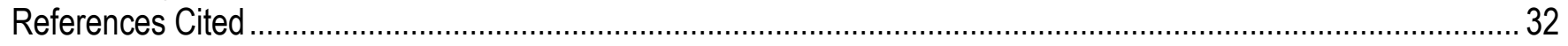




\section{Figures-Chapter 1}

Figure 1.1. Map showing locations of monitoring plots defined for this study......

Figure 1.2. Winter season precipitation (November 1 of previous year to March 1 of given breeding season) at Chemehuevi Wash, California, and Alamo Wash, Arizona.

Figure 1.3. Linear and quadratic fit of negative relationship between Black-tailed Gnatcatcher first-egg date and winter season rainfall at Chemehuevi Wash, California, and Alamo Wash, Arizona.

Figure 1.4. Proportion of first-clutch nests fledged and failed for Black-tailed Gnatcatcher and Verdin control/treatment pairs at Alamo Wash, Arizona, in 2010.

Figure 1.5. Mean percentage of eggs lost to depredation or parasitism per pair for Black-tailed Gnatcatcher and Verdin control/treatment pairs at Alamo Wash, Arizona, 2010.

Figure 1.6. Modeled nest period survival rate estimatesfor Black-tailed Gnatcatcher and Verdin control pairs, across the breeding season (Alamo Wash, Arizona, 2010).

\section{Figures-Chapter 2}

Figure 2.1. Map of study sites in Kofa National Wildlife Refuge, Yuma and La Paz Counties, Arizona.

Figure 2.2. $A$, Breeding species richness and relative abundance and $B$, Non-breeding species richness and relative abundance at burned sites in King Valley, at unburned sites in King Valley, and at control sites in Alamo Wash, 2009 and 2010

Figure 2.3. Mean percent cover by woodland species at unburned and burned xeroriparian study sites in King Valley, Arizona......

\section{Tables-Chapter 1}

Table 1.1. Male Brown-headed Cowbird arrival dates to Chemehuevi Wash and Alamo Wash

Table 1.2. Negative relationship between first-egg date and log winter season rainfall for 13 species nesting at Chemehuevi Wash, California, and Alamo Wash, Arizona.

Table 1.3. Relationship between Mayfield total nest survival and log winter season rainfall for three species nesting at Chemehuevi Wash, California and Alamo Wash, Arizona

Table 1.4. Control and treatment sample sizes for Verdins and Black-tailed Gnatcatchers at Alamo Wash, Arizona, in 2010

Table 1.5. Black-tailed Gnatcatcher and Verdin first-egg dates and confidence intervals during years following average to above-average winter rainfall seasons, during years following below-average winter rainfall seasons, and for our control and treatment pairs in 2010.

Table 1.6. Twelve candidate models for daily nest survival rates for Verdins and Black-tailed Gnatcatchers at Alamo Wash, Arizona in 2010, ranked by AICc values.

\section{Tables-Chapter 2}

Table 2.1. Number of detections by breeding species at 37 burned and 37 unburned stations in the King Valley Wash complex, Yuma County, Arizona.

Table 2.2. Number of detections by nonbreeding species at 37 burned and 37 unburned stations in the King Valley wash complex, Yuma County, Arizona.

Table 2.3. Nests located in 2009-2010 within the area affected by the King Valley burn. 


\title{
Effects of Drought and Fire on Bird Communities of the Kofa National Wildlife Refuge, Arizona
}

\author{
By Chris McCreedy ${ }^{1}$, Charles van Riper, III1,2, Todd C. Esque ${ }^{2}$ and Abigail J. Darrah ${ }^{1}$
}

\section{Executive Summary}

The U.S. Government created the Kofa National Wildlife Refuge (Kofa NWR) in 1939 in response to a citizen campaign to improve desert bighorn sheep populations in Arizona. The Kofa NWR is mountainous and remote, and its management by the U.S. Fish and Wildlife Service (FWS) keeps anthropogenic disturbance levels low. As such, Partners In Flight (PIF) listed the Kofa NWR as one of its Sonoran Desert portfolio sites in its Desert Bird Conservation Plan (McCreedy and others, 2009). Research presented here demonstrates that bird communities within a well-managed and remote Sonoran Desert portfolio site can nonetheless be negatively affected by human-caused stressors like fire and Brown-headed Cowbird (Molothrus ater) parasitism, which originate from beyond the Kofa NWR's boundaries.

In chapter 1, we examine how avian productivity can be influenced by timing of nest initiation. We demonstrate that (1) late nesting dates are correlated with low winter precipitation levels, a condition expected to occur in greater frequency in coming decades due to climate change (Seager and others, 2007) and that (2) late nesting dates result in decreased productivity, due to higher rates of nest depredation and, in the case of an open-cup nesting species, higher rates of brood parasitism experienced later in the breeding season. The brood parasite, the Brown-headed Cowbird, appears to forage and roost on agricultural lands north of the Kofa NWR's boundary. From that location, they commute to the refuge to parasitize other passerine bird nests. Drought and subsequent loss in primary production have been correlated with decreased productivity for birds that breed in arid habitats (Preston and Rotenberry, 2006; Chase and others, 2005; Johnson and others, 2002; Morrison and Bolger, 2002; Brown and Li, 1996; Anderson and Anderson, 1973), yet drought's standing as a threat to bird populations has been underestimated in recent regional conservation planning efforts (McCreedy and others, 2009; Latta and others, 1999).

In chapter 2, we examine the effects of the King Valley fire on breeding and migrant birds within the Kofa NWR. This fire was caused by incendiary weapons testing within Yuma Proving Ground, south of the Kofa NWRboundary (Esque and others, 2013). We found large differences in spring migrant and breeding species abundance and richness between bird count stations within the 2005 King Valley fire zone and bird count stations immediately outside the fire perimeter. Habitat loss to fire, and the subsequent slow regeneration of a Sonoran Desert flora that is not well adapted to fire disturbance, is a recognized threat to bird populations (McCreedy and others, 2009; Latta, 1999), and of all Sonoran Desert wildlife, birds may be the most impacted by loss of perennial Sonoran Desert vegetation to fire (Esque and Schwalbe, 2002). We conclude that decreases in both breeding and migrant use of washes within burned areas will likely persist into the long term ( $>25$ years) due to slow return rates of xeroriparian woodlands lost in the fire.

\footnotetext{
${ }^{1}$ University of Arizona.

${ }^{2}$ U.S. Geological Survey.
} 


\title{
Chapter 1-Drought-Caused Delay in Breeding and Lowered Nesting Success of Sonoran Desert Birds
}

\begin{abstract}
In southeastern California, from 2004 to 2009, we found that, among all 13 bird species for which we have sufficient sample size, the nest initiation date was later when there was less rainfall during the four-month winter rainy season preceding nesting. Nesting was delayed more than three weeks for some species during extreme droughts in 2006 and 2007. During the same period, we found nesting success to be positively associated with winter rainfall for the Black-tailed Gnatcatcher (Polioptila melanura). Because climate models are nearly unanimous in their predictions for increased drought frequency in the southwestern U.S., drought-delayed nesting may play an important role in nesting success and productivity for many Sonoran Desert bird species in the future. To investigate the effect of breeding phenology on nesting success and productivity, we conducted a manipulative experiment with Black-tailed Gnatcatchers and Verdins (Auriparus flaviceps). Following a wet winter in 2009-2010, we delayed clutch initiation dates for treatment pairs in spring 2010 to match the late firstegg dates that we had observed during previous droughts in 2006 and 2007. Undelayed first clutches had 1.8 times (Verdin) to 2.8 times (Black-tailed Gnatcatcher) higher odds of success than delayed first clutches. Diminishing daily nest survival rates over the remainder of the breeding season prohibited delayed pairs from overcoming the lost period of high productivity in March and early April, and delayed treatment pairs had lower productivity over the course of the entire breeding season than undelayed control pairs. As nest depredation and parasitism were the most common causes of nest failure, we conclude that drought impacts on annual reproductive output in the Sonoran Desert may be mediated by parasitism and depredation among Black-tailed Gnatcatchers and by depredation among Verdins.
\end{abstract}

\section{Introduction}

In arid and semiarid environments, variation in precipitation results in dramatic, short-term responses in plant and animal production - a response that is easily visible and well documented (Bolger and others, 2005; Grant and Grant, 1987; Boag and Grant, 1981; Beatley, 1969).

The connection between variation in extrinsic factors, such as rainfall, and changes in bird populations is an area of active research, and investigators have particularly sought to identify the ecological processes that influence these population fluctuations. Increases in primary production following years of above-average rainfall are correlated with increases in secondary and tertiary production due to rapid increase in food resources (Grant and Grant, 1987; Beatley, 1969; and Jaksic and others, 1997). Jaksic and others (1997) found that an increase in mammal populations following heavy rains was followed by an increase in populations of their avian and mammalian predators, moving up through trophic levels in a "bottom-up" scenario.

Working on small North American passerines, Morrison and Bolger (2002) and Chase and others (2005) found nest depredation rates were lower in wet seasons, while breeding seasons were shorter or nonexistent in dry seasons. This contrast led them to conclude that both depredation and food limitation can mediate reproductive output in response to changes in precipitation.

Sonoran Desert passerines can exhibit wide variation in the onset of their nesting, with firstclutch initiation dates spanning several weeks among years (Johnson and others 2002; Anderson and 
Anderson 1973). Several studies suggest that such year-to-year variation in breeding phenology is related to precipitation levels (Preston and Rotenberry 2006; Chase and others 2005; Johnson and others 2002; Morrison and Bolger 2002; Brown and Li 1996; Anderson and Anderson 1973), where delays in nest initiation followed periods of low rainfall.

We studied bird community richness and productivity during severe droughts in 2006 and 2007 and observed delayed nesting for all of our study species in the Sonoran Desert. Although some nesting pairs were delayed several weeks, all species save one attempted to nest during drought years.

Given that nests may have lower survival rates later in the breeding season (Grant and others, 2005; Best and Stauffer, 1980), we hypothesized that drought may decrease reproductive output by exposing nesting individuals to higher rates of depredation and parasitism than exist later in the season. We tested this hypothesis with a nesting-delay experiment following the wet winter of 2010. Assuming that our study species would not be limited by food resources in the breeding season during this wet year, we predicted that we could produce dramatic declines in nesting success and reproductive output simply by delaying nest initiation dates to match late nest initiation dates that we had recorded during drought seasons. We tested two hypotheses related to reproductive output. Initially, the first-clutch attempts of control (undelayed) pairs will have significantly higher probability of success than firstclutch attempts of delayed pairs, which will be subject to greater nest depredation and parasitism. Second, over the course of the entire season the delayed pairs will have lower nest production (successful fledging) than undelayed pairs because of increasing rates of loss to depredation and brood parasitism over the remaining season. Delayed pairs will lose a higher percentage of their eggs (per pair) to either depredation and (or) cowbird (Molothrus spp.) parasitism than control pairs.

\section{Methods}

\section{Study Sites}

Our study sites were in two Sonoran Desert wash systems: Chemehuevi Wash, California, and Alamo Wash Arizona (fig. 1.1). Sonoran Desert wash systems are similar to riparian systems, but surface water is present only during the heaviest rains. These xeroriparian corridors of the region hold significantly greater woody plant diversity than their surrounding uplands, and they consequently support much higher avian abundance and diversity (Phillips and Wentworth Comus, 1999).

Chemehuevi Wash $\left(34.45^{\circ}\right.$ N., $114.32^{\circ}$ W.) is located near the northern edge of the Sonoran Desert, in eastern San Bernardino County, California. Alamo Wash (33.51 ${ }^{\circ}$ N., $113.82^{\circ}$ W.) lies 75 miles to the southeast, in southeastern La Paz County, Arizona. Our 2 Chemehuevi Wash study plots were located at $200 \mathrm{~m}$ and $320 \mathrm{~m}$ above sea level, and our 27 Alamo Wash study plots ranged from 400 to $550 \mathrm{~m}$ above sea level.

The Chemehuevi and Alamo Wash systems are similar, dominated by leguminous phreatophytes of the blue paloverde-desert ironwood (Parkinsonia florida-Olneya tesota) woodland alliance (Sawyer and Keeler-Wolf, 2009). Dominant trees include blue paloverde, desert ironwood, catclaw acacia (Acacia greggii), yellow paloverde (Parkinsonia microphylla), and honey and velvet mesquite (Prosopis glandulosa and P. velutina). 


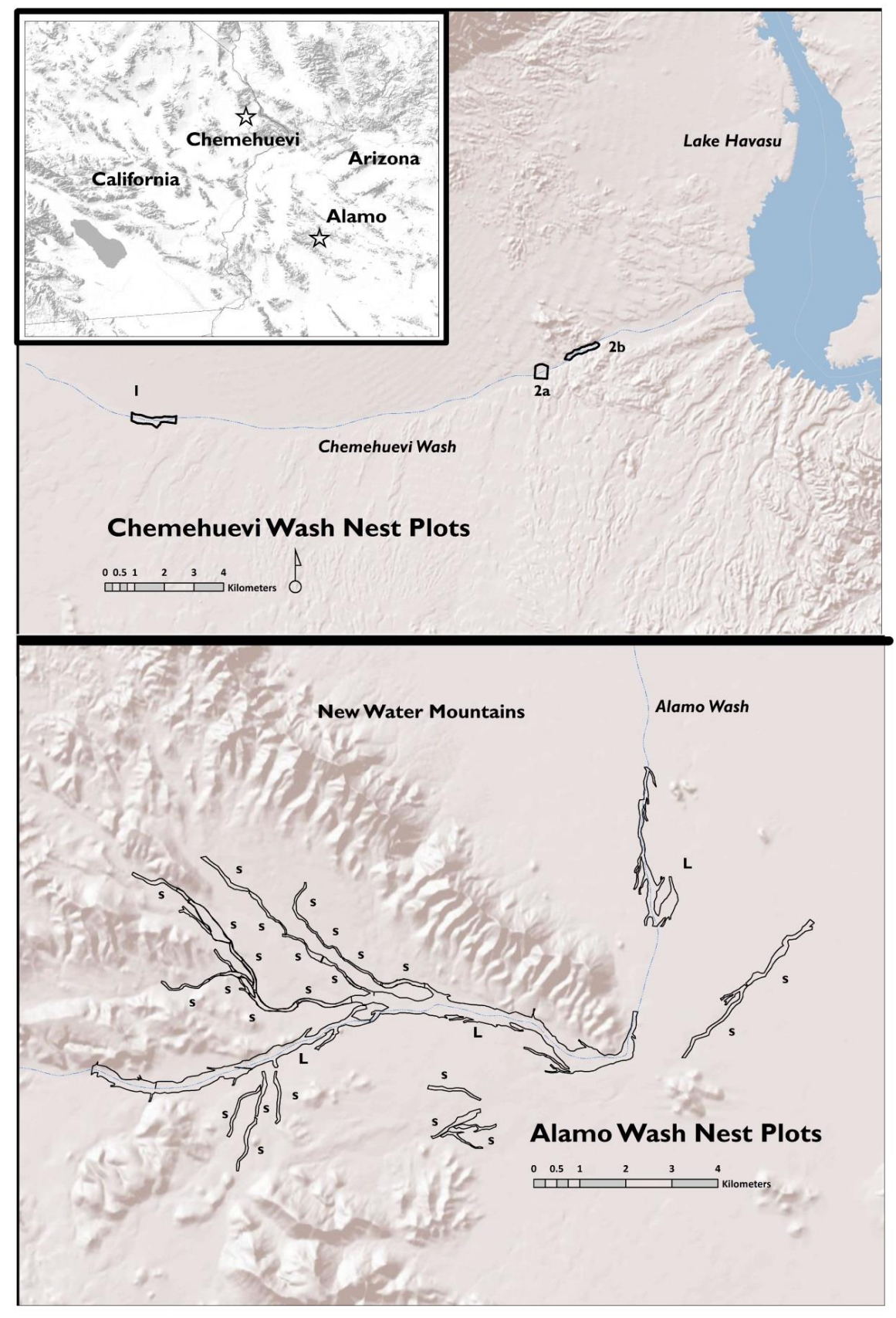

Figure 1.1. Map showing locations of monitoring plots defined for this study. (upper) Chemehuevi Wash, San Bernardino County, California) nest monitoring plots, 2004-2008 and (lower), Alamo Wash, La Paz County, Arizona nest monitoring plots, 2009-2010. From McCreedy and van Riper (2015). L, large wash study area; s, small wash study area. 


\section{Study Species}

Black-tailed Gnatcatchers (Polioptila melanura) and Verdins (Auriparus flaviceps) are small, resident passerines whose geographic ranges are largely within the Mojave, Sonoran and Chihuahuan Deserts (Farquhar and Ritchie, 2002; Webster, 1999). They are among the most common breeding species found at our study sites (Sullivan and others, 2009). The two species can be found gleaning together in mixed flocks, and they appear to share overlapping diets of small insects and spiders. Young of both species are provisioned primarily with small caterpillars and spiders. Both species may occasionally consume fruit and seeds, although this is likely more common in Verdins, particularly in the nonbreeding season (Farquhar and Ritchie, 2002; Webster, 1999).

Both species share long breeding seasons, with nest-building commencing as early as midFebruary in favorable conditions, and nestlings can be found well into August depending on occurrence and intensity of summer monsoon rains (Farquhar and Ritchie, 2002; Webster, 1999). Verdins build a complex, spherical dome nest with a small entrance (Webster, 1999), while Black-tailed Gnatcatchers construct open-cup nests. Consequently, Black-tailed Gnatcatchers are more susceptible to brood parasitism by the Brown-headed Cowbird (Molothrus ater) than are Verdins (Farquhar and Ritchie, 2002). In the Sonoran Desert, both Black-tailed Gnatcatchers and Verdins are highly dependent upon wash systems for foraging and particularly for nesting substrates.

Both species typically lay from 3 to 5 eggs in a clutch (usually 4). Black-tailed Gnatcatchers incubate for 14 to 15 days, and nestlings will fledge at 15 days but may fledge at as early as 9 days (Farquhar and Ritchie, 2002). Verdins incubate for 14 to 18 days, and nestlings often fledge by day 18 (Webster, 1999).

\section{Precipitation}

The Sonoran Desert has two distinct precipitation periods: winter rains (November through February) that fall from cyclonic frontal systems following storm tracks from the Pacific Ocean, and summer monsoon rains that fall from convective thunderstorms driven by tropical moisture from the Gulf of California (July through September). Winter storms are characterized by relatively prolonged, gentle, rains with broad geographic patterns of accumulation. Summer monsoon rains are generally much more localized and severe than winter rains (National Oceanic and Atmospheric Administration, 1985). The two seasons are separated by relatively dry periods in the spring (May-June) and autumn (October).

We summarized daily rainfall values for Chemehuevi Wash (2003-2008) and Alamo Wash (2008-2010) from archived weather station data (available from the National Climatic Data Center, at http://www.wrcc.dri.edu/summary/Climsmaz.html) utilizing mean accumulations recorded at the three weather stations nearest to each study site. For Chemehuevi Wash, we compiled data from the Lake Havasu City, Parker Reservoir, and Parker stations. For Alamo Wash, we pulled data from the Kofa Mine, Dateland Ranch, and Quartzsite weather stations. In the event of a missing value, we substituted the day's precipitation from the fourth-closest site (Needles for Chemehuevi and Bouse for Alamo).

We defined winter-season rainfall as the four-month (pre-breeding season) period from November 1 of the previous calendar year through March 1, which captured the breeding season's preceding winter storm cycles and any precipitation near the onset of nesting.

To examine whether summer and (or) autumn rainfall preceding the winter rainy season affected nest initiation dates, we also defined a 6-month lag (September 1 through March 1), which captured autumn storms driven by late-season tropical moisture from the Gulf of California, and a 10-month lag 
(May 1 through March 1), which captured summer, autumn, and winter rainfall during the year preceding nesting.

\section{Spot-Mapping and Nest Monitoring}

\section{Chemehuevi Wash, 2004-2008}

We established two 40-hectare nest monitoring plots on the Chemehuevi Wash in February 2004 (fig.1.1). From February through May each season (2004-2008), we used standardized spot-mapping protocols following guidelines suggested by the International Bird Census Committee (1970) and by Ralph and others (1993). We used Universal Transverse Mercator-gridded maps with Garmin Global Positioning System receivers to record nest locations.

We located and monitored nests following protocols described in Martin and Geupel (1993) and Martin and others (1997), with nest-check intervals generally four days in length. We recorded nest contents, nestling age, and instances of cowbird parasitism on each visit. We determined outcomes for all nests, and only used nests with known fates in analyses. Nests were considered to have fledged young if we saw or heard fledglings at the nest site, observed repeated food carries by adults to fixed locations, or observed whitewash on twigs around the nest combined with parent scolding. We typically spent up to 45 minutes ascertaining success or failure at nests that we found to be empty.

Alamo Wash, 2009

In January 2009, we established 4 3-km-long plots within Alamo Wash, and 23 1-km-long plots on secondary tributaries throughout the Alamo Basin (fig. 1.1). We randomly ordered plots with the objective of monitoring nesting success and reproductive output of 30 Black-tailed Gnatcatcher pairs on the primary wash and 30 pairs on secondary washes. We spot-mapped territories and monitored nests from February 1 to May 31.

\section{Nest Delay Experiment}

To investigate an apparent relationship between drought conditions in 2006 and 2007 and late nesting dates, we delayed clutch initiation dates for Verdins and Black-tailed Gnatcatchers at the Alamo Wash during a wet year in 2010. Our objective was to generate distributions of first-egg dates for treatment pairs that were similar to distributions of first-egg dates found during drought years. Once plot order was established, we generated a random number table assigning control and treatment status for territory numbers for each species. We then assigned territory numbers (and hence randomized control and treatment status) in the chronological order in which we located nests. We followed spot mapping and nest monitoring protocols described above, and began delaying Verdin nests on March 6 and Blacktailed Gnatcatchers on March 21. Control pairs were left to continue nesting without delay.

We delayed treatment pairs during nest construction by opening the nest wall as building approached completion (Experimental protocol was approved prior to the 2010 season by the Institutional Animal Care and Use Committee [Protocol \#10-154]). We waited for pairs to leave so that we would not be seen at the nest, and each nest manipulation generally required less than five seconds to perform. We opened the nest as minimally as possible to (1) ensure that the pairs could recycle all materials for their subsequent re-nest and (2) ensure that material did not fall to the ground, potentially attracting predators. 
We then located each treatment pair's subsequent re-nest and repeated the process as necessary, until 5-7 days prior to our target mean first-egg dates (April 9 for Verdin and April 15 for Black-tailed Gnatcatchers). We did not wish to cause failure of any established clutches, thus we needed to find renest attempts quickly, before egg-laying commenced. We achieved this by focusing nest searching efforts on the second or third day after delay, when delayed pairs were most likely to be found recycling material from the previous nest. This scheduling also helped further confirm pairs' identities from previous nest attempts. We then monitored success of treatment and control nests through the completion of the last active nest of the season (the last week of July).

\section{Statistical Analyses}

\section{Nest Initiation Date, Mayfield Nest Survival, and Winter Season Rainfall}

We used nest-check observations and backdating to calculate annual mean first-egg dates for all species at the Chemehuevi Wash (2004-2010), for Black-tailed Gnatcatchers at Alamo Wash in 2009, and for Black-tailed Gnatcatchers and Verdins at Alamo Wash in 2010.

We calculated annual Mayfield success estimates at Chemehuevi Wash from 2004-2008 and at Alamo Wash in 2009, pooling exposure periods to obtain estimates of survival over the entire nest cycle (Johnson, 1979; Mayfield, 1975).

We used simple linear regression to test quadratic and linear relationships between logtransformed winter season rainfall and first-egg date (Bolger and others, 2005). We then examined summed winter + autumn rainfall and winter + autumn + summer rainfall to test whether greater time lags improved correlations. To investigate patterns between winter season rainfall and Mayfield success rate, we used simple linear regression to test quadratic and linear relationships between log-transformed winter season rainfall and Mayfield nest survival estimates.

\section{Delay Experiment}

As we knew all clutch initiation dates, outcomes, and found all study pairs' first-clutch nests, we compared differences in the proportional success (rather than estimates of nesting success) of control and treatment first-clutch attempts with logistic regression.

We also investigated annual reproductive output by comparing loss of eggs (per pair) to depredation and (or) parasitism experienced by treatment versus control pairs during the 2010 breeding season. To increase accuracy of fledgling counts, we allocated the effort necessary (occasionally multiple visits and days) to find and count the total number of fledglings for each successful nest.

We did not have sufficient sample size to assess treatment effect by comparing success rates of treatment pairs at various amounts of delay. As an indirect assessment of treatment effect, we used the logistic exposure method (Shaffer, 2004; Shaffer and Thompson, 2007) to model and plot period survival estimates for control pairs over the entire breeding season. Following Shaffer and Thompson (2007), we used PROC GENMOD (in SAS version 9.2) to estimate daily survival parameters (Shaffer, 2004), and then used the information-theoretic approach (Burnham and Anderson, 2002) to rank 12 candidate models that described hypothesized effects of rainfall and nest initiation date on nest survival following biological rationales for the basic models presented in Grant and others (2005). Models evaluated (1) constant survival throughout the season, (2) linear, and (3) nonlinear (quadratic) date terms, and (4) linear, (5) quadratic, and (6) cubic nest-age terms. Models were ranked using Akaike's Information Criterion adjusted for small sample size (AIC ; Burnham and Anderson 2002). 
Once we selected the models for Verdins and Black-tailed Gnatcatchers that best explained our data, we calculated model-averaged daily survival rates and their lower and upper confidence interval bounds by each nest age to generate period nest survival estimates (Verdin period, 38 days; Black-tailed Gnatcatcher period, 31 days) to plot against survival nest initiation dates (Grant and others 2005).

\section{Results}

\section{Rainfall}

Historical mean winter season rainfall for the three weather stations nearest Chemehuevi Wash (1893-2010) and three stations nearest Alamo Wash (1952-2010) are nearly identical (cHEM $=54.78$ $\mathrm{mm}, \mathrm{ALAMO}=58.76 \mathrm{~mm}$; data are from the Western Regional Climate Center, available at http://www.wrcc.dri.edu/climate-summaries).

Annual winter season rainfall varied dramatically during 2003-2010 (fig. 1.2). The 2005 winter rainy season was one of the region's wettest on record-over five times of the historical mean. The 2006 and 2007 winters were two of the driest, each totaling only about 10 percent of the historical mean (fig. 1.2).

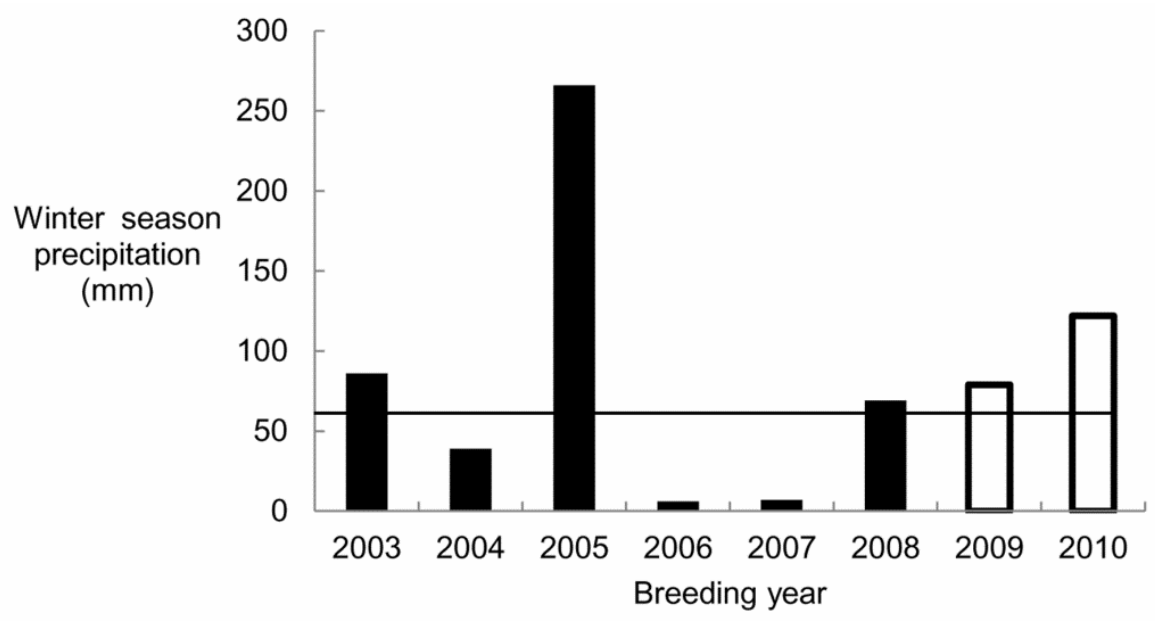

Figure 1.2. Winter season precipitation (November 1 of previous year to March 1 of given breeding season) at Chemehuevi Wash, California, and Alamo Wash, Arizona. Chemehuevi Wash accumulations for 2003-2008 (black) and Alamo Wash accumulations for 2009-2010 (white). Historical mean winter season rainfall is $55 \mathrm{~mm}$ at the Chemehuevi Wash and $59 \mathrm{~mm}$ at Alamo Basin, shown by the horizontal black line.

The period leading up to our 2010 nest delay experiment, from summer 2009 to winter 2010, was notable in its extremes. The 2009 summer monsoon and autumn were abnormally dry, and 2009 was the seventh-driest year in recorded history in Phoenix, Arizona. This drought was interrupted by a rapid series of violent late-January storms, which the National Weather Service gauged to be a 25-year event (National Weather Service, 2010).

\section{Cowbird Arrival Date}

Male Brown-headed Cowbirds arrived on territory within a 9-day window each year of our study, from March 26 to April 1 (table 1.1). Cowbirds normally winter in the region, typically in 
agricultural areas and feedlots (Corman and Wise-Gervais, 2005). However, they were absent from our study plots during the winter, and their first arrival was conspicuous. Males arrived first, followed by females that arrived approximately 2-3 weeks later. We found no evidence that winter season rainfall influenced cowbird arrival date $(Y=87.63+0.01 X, P=0.36, R 2=0.21, n=6$ years, simple linear regression), although the two years of earliest cowbird arrival were during droughts, in 2006 and 2007.

Table 1.1. Male Brown-headed Cowbird arrival dates to Chemehuevi Wash (2004-2008) and Alamo Wash (2010).

\begin{tabular}{ll}
\hline \hline Year & Date \\
\hline 2004 & March 30 \\
2005 & March 28 \\
2006 & March 24 \\
2007 & March 25 \\
2008 & March 30 \\
2009 & No data \\
2010 & April 1 \\
\hline
\end{tabular}

\section{Winter Season Rainfall and Nest Initiation}

We identified a negative correlation between winter season rainfall and first-egg date for 13 of 13 species with sufficient sample size (table 1.2). Addition of the preceding autumn and summer monsoon season to the rainfall dataset did not improve the predictability of this relationship. Blacktailed Gnatcatchers were the only species for which the addition of a quadratic term markedly improved model fit, perhaps due to greater sample size (fig. 1.3).

Table 1.2. Negative relationship between first-egg date and log winter season rainfall for 13 species nesting at Chemehuevi Wash, California (2004-2008), and Alamo Wash, Arizona (2009).

[Species ordered by increasing $P$-values (simple linear regression)]

\begin{tabular}{|c|c|c|c|c|c|c|c|}
\hline \multirow[b]{2}{*}{ Species } & \multirow[b]{2}{*}{ Years } & \multirow[b]{2}{*}{ Nests } & \multirow[b]{2}{*}{ Coefficient } & \multicolumn{4}{|c|}{ Upper Cl } \\
\hline & & & & Lower Cl Bound & Bound & $P$ & $R^{2}$ \\
\hline Black-tailed Gnatcatcher (Polioptila melanura) & 6 & 135 & -26.70 & -36.96 & -16.43 & 0.001 & 0.93 \\
\hline Greater Roadrunner (Geococcyx californianus) & 4 & 10 & -31.54 & -46.16 & -16.91 & 0.01 & 0.98 \\
\hline Verdin (Auriparus flaviceps) & 5 & 98 & -13.08 & -20.68 & -5.49 & 0.01 & 0.91 \\
\hline Ash-throated Flycatcher (Myiarchus cinerascens) & 4 & 30 & -22.71 & -38.60 & -6.81 & 0.03 & 0.95 \\
\hline Bendire's Thrasher (Toxostoma bendirei) & 4 & 8 & -33.23 & -63.88 & -2.57 & 0.04 & 0.92 \\
\hline Black-throated Sparrow (Amphispiza bilineata) & 4 & 4 & -29.08 & -61.28 & 3.12 & 0.06 & 0.88 \\
\hline Mourning Dove (Zenaida macroura) & 5 & 20 & -15.44 & -32.16 & 1.29 & 0.06 & 0.74 \\
\hline Costa's Hummingbird (Calypte costae) & 5 & 29 & -14.51 & -30.49 & 1.47 & 0.06 & 0.74 \\
\hline House Finch (Haemorhous mexicanus) & 5 & 67 & -17.92 & -38.03 & 2.18 & 0.07 & 0.73 \\
\hline Crissal Thrasher (Toxostoma crissale) & 6 & 16 & -42.05 & -88.86 & 4.77 & 0.07 & 0.61 \\
\hline Loggerhead Shrike (Lanius ludovicianus) & 5 & 57 & -17.32 & -37.54 & 2.90 & 0.07 & 0.71 \\
\hline Phainopepla (Phainopepla nitens) & 4 & 161 & -10.54 & -28.80 & 7.71 & 0.13 & 0.76 \\
\hline Lucy's Warbler (Oreothlypis luciae) & 5 & 37 & -5.24 & -20.45 & 9.70 & 0.35 & 0.29 \\
\hline
\end{tabular}




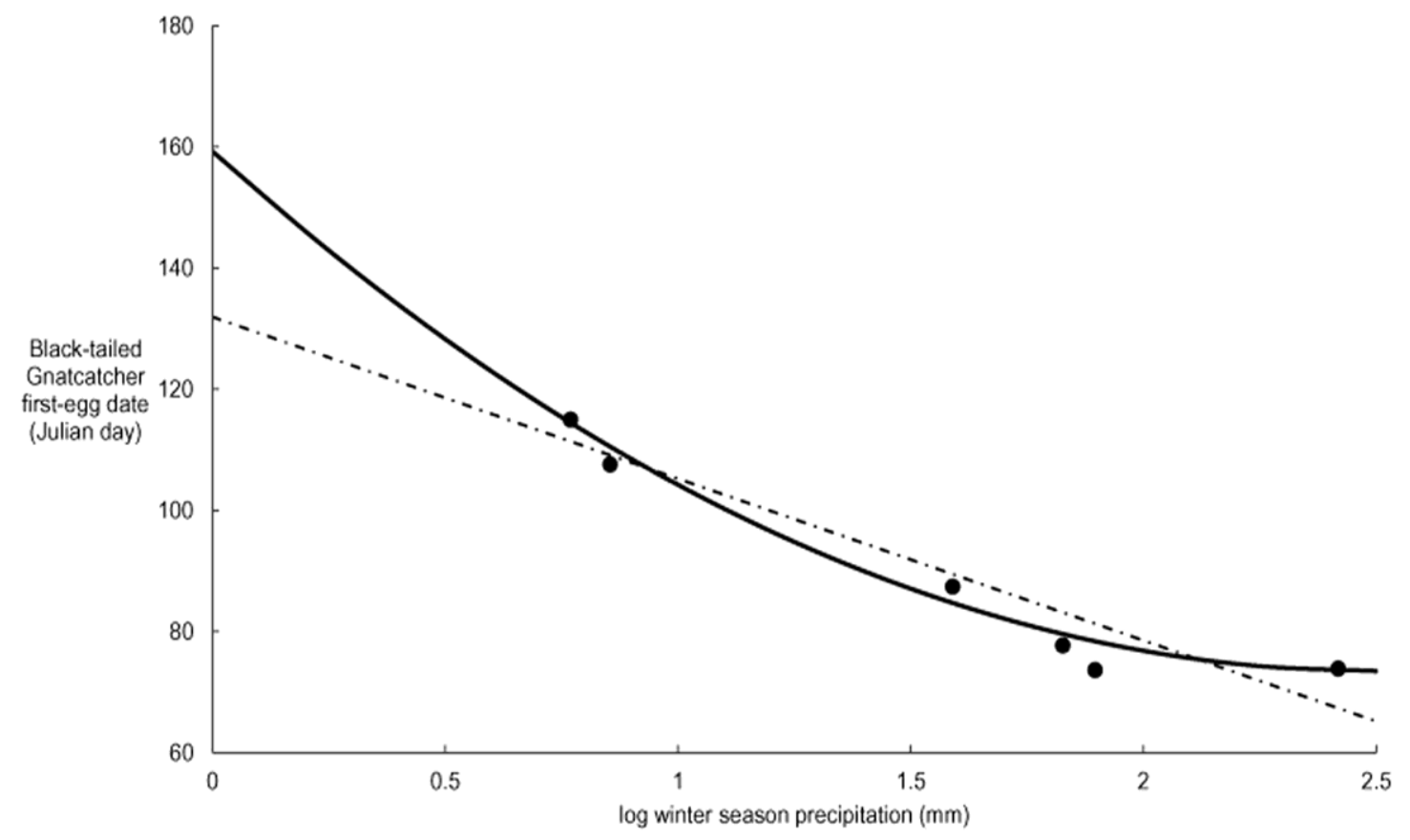

Figure 1.3. Linear (dashed) and quadratic (solid) fit of negative relationship between Black-tailed Gnatcatcher firstegg date and winter season rainfall at Chemehuevi Wash, California, and Alamo Wash, Arizona (2004-2009). The linear model is $y=131.9-26.7 x, P=0.002, R^{2}=0.93$, and the polynomial model is $y=159.2-68.8 x+13.8 x^{2}, P=$ $0.001, R^{2}=0.99$.

\section{Winter Season Rainfall and Mayfield Nest Survival}

For five years preceding our 2010 nest-delay experiment, we found positive, linear correlations between nest survival and winter season rainfall for 2 of 3 species for which we had a sufficient number of nests for the analysis (table 1.3).

Table 1.3. Relationship between Mayfield total nest survival and log winter season rainfall for three species nesting at Chemehuevi Wash, California (2004-2008) and Alamo Wash, Arizona (2009).

[Species ordered by increasing $P$-values, (simple linear regression)]

\begin{tabular}{lccccccc}
\multicolumn{1}{c}{ Species } & Years & Nests & Coefficient & Lower Cl Bound & Upper ClBound & $\boldsymbol{P}$ & $\boldsymbol{R}^{2}$ \\
\hline Black-tailed Gnatcatcher (Polioptila melanura) & 6 & 170 & 0.29 & 0.23 & 0.34 & 0.0001 & 0.98 \\
Phainopepla (Phainopepla nitens) & 5 & 173 & 0.30 & 0.00 & 0.60 & 0.05 & 0.77 \\
Verdin (Auriparus flaviceps) & 5 & 129 & 0.04 & -0.14 & 0.21 & 0.57 & 0.12 \\
\hline
\end{tabular}

\section{Nest Delay Experiment, 2010: Comparison of Control and Delayed First-Clutch Attempts}

Mean 2010 first-egg dates for control pairs were later than expected for each species, given above average winter rainfall totals. This slightly delayed initiation resulted in a less dramatic difference in first-egg dates between Black-tailed Gnatcatcher control and treatment pairs (17 days) than previously found between previous wet and dry years (30 days, tables 1.4 and 1.5). 
Table 1.4. Control and treatment sample sizes for Verdins and Black-tailed Gnatcatchers at Alamo Wash, Arizona, in 2010. Sample unit is one pair.

\begin{tabular}{lllll}
\hline \multicolumn{1}{c}{ Species } & Control & Actual & Treatment & Actual \\
\hline Verdin & 60 & 60 & 60 & 51 \\
Black-tailed Gnatcatcher & 60 & 36 & 60 & 39 \\
\hline
\end{tabular}

Table 1.5. Black-tailed Gnatcatcher and Verdin first-egg dates and confidence intervals (Cl) during years following average to above-average winter rainfall seasons, during years following below-average winter rainfall seasons, and for our control and treatment pairs in 2010.

\begin{tabular}{|c|c|c|c|c|c|c|}
\hline Species & Average to wet winters & $\begin{array}{c}\text { Average first egg date } \\
\text { ( } n \text { pairs) }\end{array}$ & $\begin{array}{c}\mathrm{Cl} \\
\text { (in days) }\end{array}$ & Drought winters & $\begin{array}{l}\text { Average first egg date } \\
\text { ( } n \text { pairs) }\end{array}$ & $\begin{array}{c}\mathrm{Cl} \\
\text { (in days) } \\
\end{array}$ \\
\hline \multirow{4}{*}{$\begin{array}{l}\text { Black-tailed } \\
\quad \text { Gnatcatcher } \\
\text { Verdin }\end{array}$} & 2004,2005 , and 2008 & March 16 (26) & \pm 2.1 & 2006,2007 & April 15 (19) & \pm 3.0 \\
\hline & 2010 CONTROL & March 30 (36) & \pm 1.5 & 2010 TREATMENT & April 16 (40) & \pm 1.5 \\
\hline & 2004,2005 , and 2008 & March 15 (36) & \pm 1.7 & 2006,2007 & April 9 (42) & \pm 1.7 \\
\hline & 2010 CONTROL & March 22 (60) & \pm 0.8 & 2010 TREATMENT & April 16 (51) & \pm 3.1 \\
\hline
\end{tabular}

We found proportional nesting success to be significantly higher for control pairs than for treatment pairs for first clutch nests of both study species (fig. 1.3). The difference was greater for Black-tailed Gnatcatchers, whose control nests had 2.8 times higher odds of success than treatment nests (95-percent confidence interval 1.7-5.1, $P<0.001, n=76$ ). While the majority (61 percent) of gnatcatcher control nests fledged, only 18 percent of treatment nests were successful. Control Verdin nests had 1.8 times higher odds of success than treatment nests (95-percent confidence interval 1.2-2.9, $P=0.009$, $n=111$ ). Only 61 percent of Verdin treatment nests were successful, while 87 percent of the control firstclutch attempts fledged young.

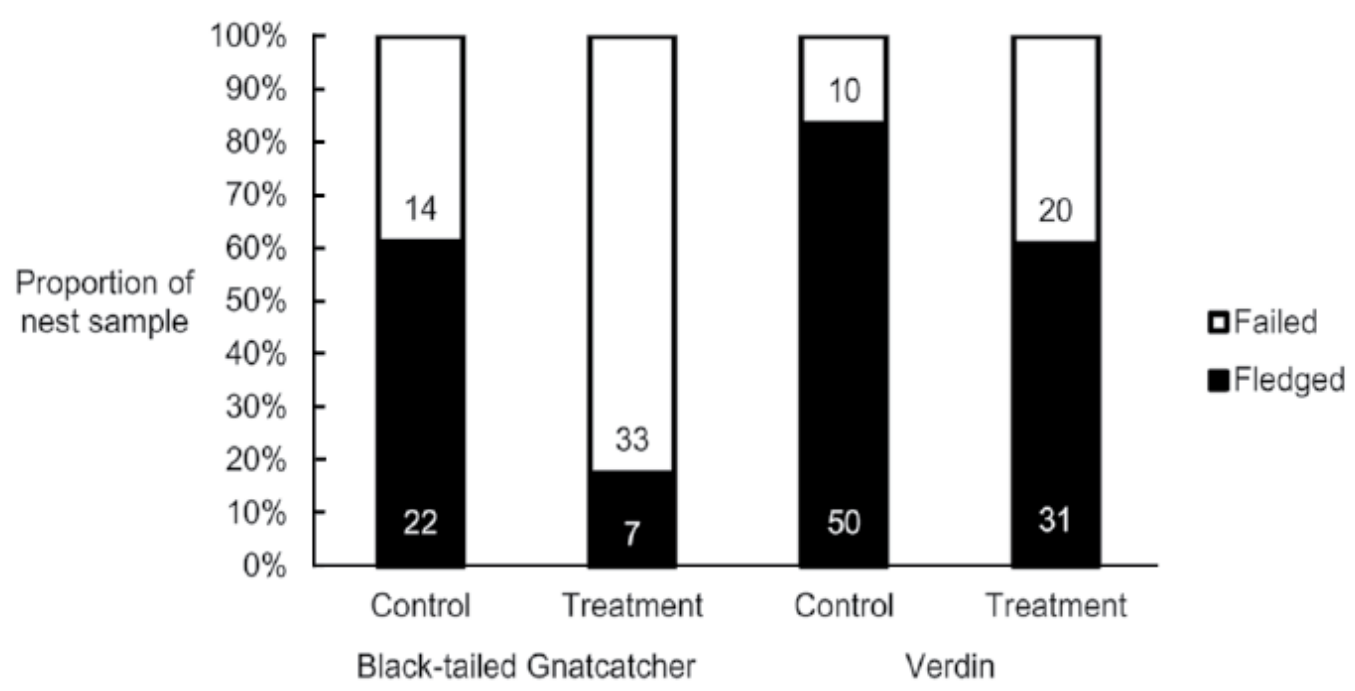

Figure 1.4. Proportion of first-clutch nests fledged and failed for Black-tailed Gnatcatcher and Verdin control/treatment pairs at Alamo Wash, Arizona, in 2010. Nest counts are displayed in their respective bars.

Over the course of the entire breeding season, the delayed treatment pairs for both species were more likely to lose eggs to depredation and (or) parasitism than control pairs (fig. 1.3). The percentage of gnatcatcher eggs lost (per pair) over the course of the season to depredation and (or) parasitism was significantly different when comparing control and treatment pairs (mean $=25.6$ percent, 95-percent 
confidence interval 11.9-39.3 percent, one-sided $P=0.0002, d f=74)$. This difference was not as pronounced between Verdin control and treatment pairs (mean $=15.1$ percent, 95-percent confidence interval $0.0-30.2 \%$, one-sided $P=0.02, d f=109$ ).

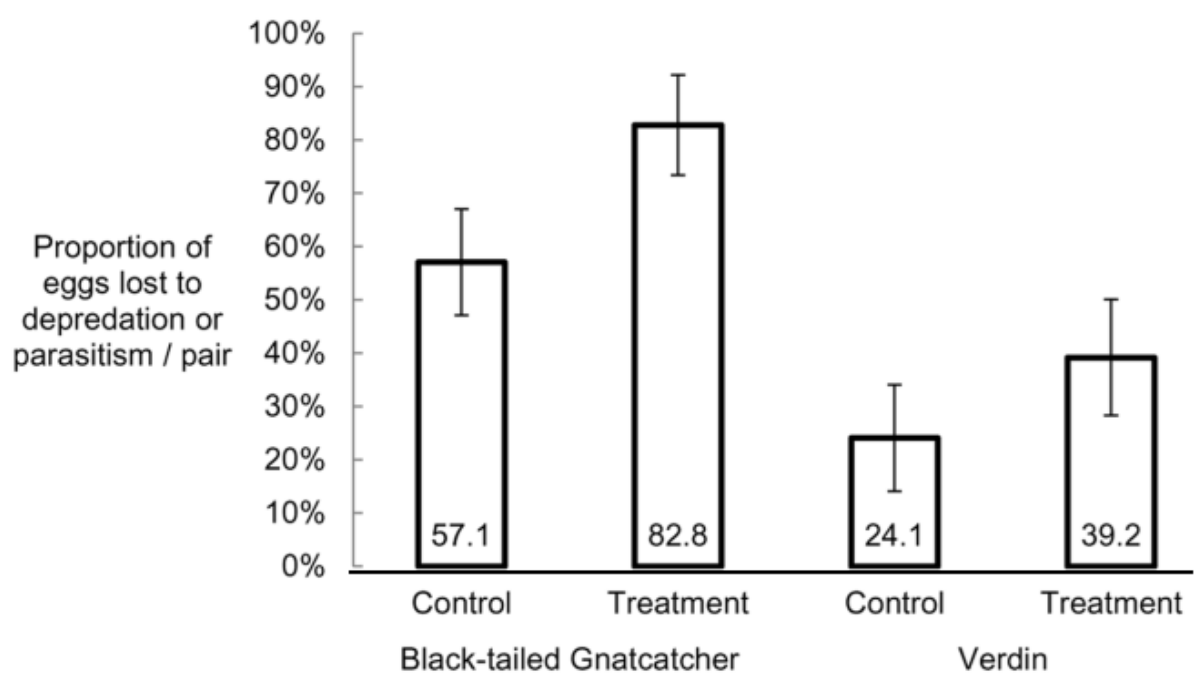

Figure 1.5. Mean percentage of eggs lost to depredation or parasitism per pair (bars show 95-percent confidence intervals) for Black-tailed Gnatcatcher and Verdin control/treatment pairs at Alamo Wash, Arizona, 2010.

\section{Time-Dependent Decrease in Nest Survival}

A polynomial model with quadratic and linear date terms best described nest daily survival rates for Black-tailed Gnatcatchers control pairs, while a similar model with the addition of a linear nest age term best described daily survival rates for Verdins (table 1.6). Period survival declined dramatically over the course of the season for both Black-tailed Gnatcatcher and Verdin control pairs (fig. 1.7). Though gnatcatcher control pairs continued to attempt clutches into mid-July, the last gnatcatcher clutch to fledge was completed on June 5, six weeks prior to the end of the laying season. 
Table 1.6. Twelve candidate models for daily nest survival rates for Verdins and Black-tailed Gnatcatchers at Alamo Wash, Arizona in 2010, ranked by AICc values.

[Loglike is the value of the maximized log-likelihood function, $\mathrm{k}$ is the number of parameters in the model, AIC c $_{\mathrm{c}}$ Akaike's Information Criterion value for small sample size, deltaAIC ${ }_{c}$ is the scaled value of $\mathrm{AIC}_{\mathrm{c}}$ ModLik is the probability of the data given the model. al, linear nest age; aq, quadratic nest age, ac, cubic nest age; dl, linear date; dq,

\begin{tabular}{|c|c|c|c|c|c|c|c|}
\hline al dl dq & -142.596 & 285.193 & 3 & 291.214 & 0 & 0.562 & 1 \\
\hline al aq ac dl & -152.591 & 305.183 & 4 & 313.219 & 22.005 & 0 & 0 \\
\hline $\mathrm{al} \mathrm{aq} \mathrm{ac}$ & -153.848 & 307.696 & 3 & 313.718 & 22.504 & 0 & 0 \\
\hline al aq dl & -168.607 & 337.215 & 3 & 343.236 & 52.022 & 0 & 0 \\
\hline al dl & -177.574 & 355.147 & 2 & 359.158 & 67.944 & 0 & 0 \\
\hline al aq ac dl dq & -177.574 & 355.147 & 2 & 359.158 & 67.944 & 0 & 0 \\
\hline al aq dl dq & -177.574 & 355.147 & 2 & 359.158 & 67.944 & 0 & 0 \\
\hline $\mathrm{dl}$ & -195.966 & 391.932 & 1 & 393.936 & 102.722 & 0 & 0 \\
\hline al & -209.146 & 418.292 & 1 & 420.295 & 129.081 & 0 & 0 \\
\hline \multicolumn{8}{|c|}{ Black-tailed Gnatcatcher } \\
\hline al aq ac dl & -140.268 & 280.536 & 4 & 288.552 & 19.967 & 0 & 0 \\
\hline al aq dl & -163.74 & 327.481 & 3 & 333.49 & 64.905 & 0 & 0 \\
\hline al dl & -167.66 & 335.32 & 2 & 339.325 & 70.74 & 0 & 0 \\
\hline al aq ac dl dq & -167.66 & 335.32 & 2 & 339.325 & 70.74 & 0 & 0 \\
\hline al aq dl dq & -167.66 & 335.32 & 2 & 339.325 & 70.74 & 0 & 0 \\
\hline $\mathrm{dl}$ & -168.924 & 337.847 & 1 & 339.849 & 71.265 & 0 & 0 \\
\hline al aq & -193.834 & 387.667 & 2 & 391.672 & 123.088 & 0 & 0 \\
\hline al & -268.891 & 537.782 & 1 & 539.784 & 271.2 & 0 & 0 \\
\hline
\end{tabular}




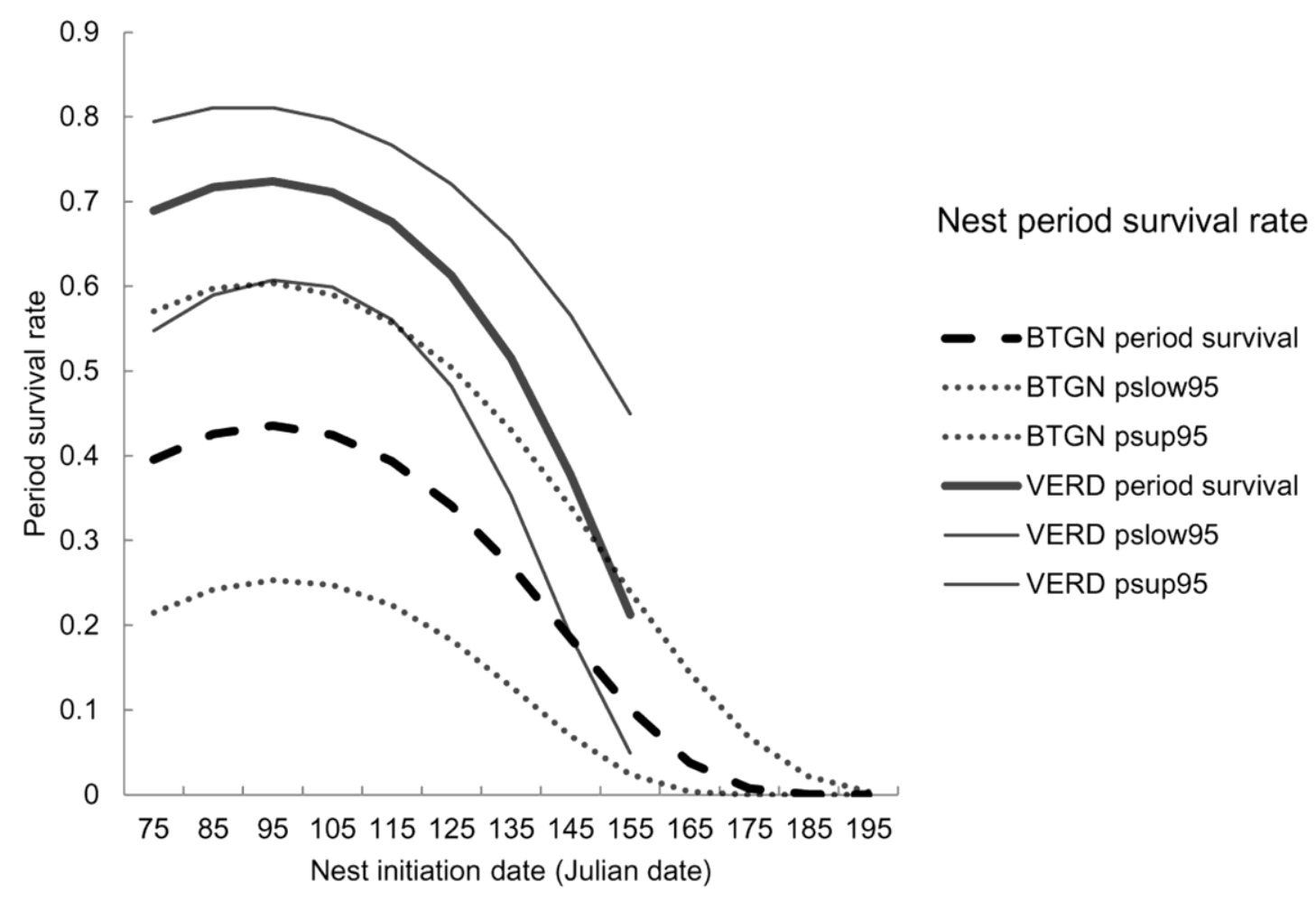

Figure 1.6. Modeled nest period survival rate estimates (with 95-percent confidence intervals) for Black-tailed Gnatcatcher and Verdin control pairs, across the breeding season (Alamo Wash, Arizona, 2010). Pslow95 and psup95 lines represent upper and lower 95-percent confidence interval bounds on modeled nest period survival. Julian Date numbering commences January 1 (Julian day 1), thus, Julian day 75 is March 15; 105 is April 14; 135 is May 14; 165 is June 13; and 195 is July 13.

\section{Discussion}

\section{Climate Change Projections Suggest Delayed Phenology in the Sonoran Desert}

Eighteen models used in the Intergovernmental Panel on Climate Change's Fourth Assessment Report predicted drier conditions in southwestern North America, with increased frequency of severe droughts (Seager and others, 2007). These models predicted that higher aridity in spring and summer will result from decreased winter precipitation. At Chemehuevi Wash, we observed dramatic delays in nest initiation that, for some species, extended several weeks following dry winters in 2006 and 2007.) Greater frequency of drought conditions in the future suggests that nest initiation delays will occur with greater frequency.

We found that all 13 of our study species experienced delayed nesting following winters of low rainfall. Delays extended over three weeks for some species during the 2006 and 2007 drought. The negative relationship between winter season precipitation and Julian date for the first egg date $P$-values of $\leq 0.07$ explained more than 70 percent of the variation in first-egg date across years for 11 of these species. Of the two species with weakest statistical relationship between rainfall and first-egg date, one (Phainopepla, Phainopepla nitens) failed to nest during a dry year, and the other (Lucy's Warbler, Oreothlypis luciae) seems to be less affected by drought conditions because of its migration pattern. None of the Phainopepla pairs we observed nested during the dry spring of 2006. Had they initiated clutches, however, their expected clutch date — given 2006's low winter rainfall—would probably have 
been later, and therefore, would have strengthened the observed relationship between rainfall and firstegg date (projected $P=0.04, R^{2}=0.81, n=5$ years). Lucy's Warblers (Oreothlypis luciae), which expressed the weakest relationship between winter rainfall and nest timing, are short-distance migrants. They are the last of the study sites' breeding species to arrive in the spring, generally begin nesting soon after arriving, and their limited presence on drought-stricken breeding grounds limits their exposure to conditions that appear to cause a higher degree of delayed initiation in other species.

Our findings are contrary to multiple examples at higher latitudes in North America and Europe, where scientists have found long-term trends of earlier nesting in response to changing climate (Crick, 2004; Both and Visser, 2001; Brown and others, 1999; Crick and Sparks, 1999; Dunn and Winkler, 1999). In those examples, earlier nest initiation dates were tied to increasing temperatures. Increasing temperatures also may have some effect on nest initiation in the Sonoran Desert, but temperature differences seem to be obscured by the effect of low rainfall. Other investigators have found droughtrelated delay in nest initiation dates in arid or semi-arid regions (Preston and Rotenberry, 2006; Chase and others, 2005; Johnson and others, 2002; Morrison and Bolger, 2002; Brown and Li, 1996; Anderson and Anderson, 1973), perhaps representing a widespread response of birds nesting in ecosystems with low and infrequent precipitation.

\section{Delay Experiment}

In 2010, we found that experimentally delaying nest initiation for Black-tailed Gnatcatchers and Verdins, designed to match nest initiation dates observed during drought years, had negative consequences for our study species' nesting success and productivity. First clutches of treatment (delayed) pairs had significantly lower odds of success than first clutches of control (not delayed) pairs. Due to declining nest survival rates over the remainder of the season, delayed treatment pairs were excluded from relatively high nest survival experienced by undelayed control pairs early in the season, never experiencing this period of high nest survival. Treatment pairs consequently lost higher percentages of their eggs to depredation or brood parasitism over the course of the breeding season than control pairs. Low nesting survival rates of treatment pairs that were observed during the 2010 experiment mirrored low nest success and productivity that we previously observed at the Chemehuevi Wash following dry winters.

Researchers have previously found that arthropod density tracks rainfall, and thus, primary production in the Chihuahuan Desert (Whitford and Creusere, 1977) and in southwestern California (Bolger and others, 2005). Those findings suggest that primary production and arthropod density were both high within our experimental plots in 2010, which followed a wet winter season. While low food availability during drought years correlated with delayed nest initiation, we found that both Black-tailed Gnatcatchers and Verdins still nested during severe droughts in 2006 and 2007. Given wet conditions in 2010 and the ability of our study species to nest in severe drought conditions with low primary and secondary productivity, we do not believe food availability decreased dramatically enough during 2-3 weeks of experimental delay affect our delayed-nesting pairs. Yet by delaying the treatment pairs' firstegg dates 2-3 weeks, we produced low nest success and low productivity rates that were similar to what we observed during the droughts in 2006 and 2007. Depredation and brood parasitism were the most common causes for nest failure in 2010, and the lower nesting success of treatment pairs suggests that nests with later initiation dates are exposed to greater rates of depredation and parasitism than nests with early initiation dates. 


\section{Factors Affecting Avian Reproductive Success During Drought}

The effects of food (driven by variation in rainfall) on avian reproductive success in arid habitats have been documented by several investigators (Preston and Rotenberry, 2006; Bolger and others, 2005; Grant and Grant, 1987; Boag and Grant, 1981). Chase and others (2005) and Morrison and Bolger (2002) found that predator-mediated processes could drive annual changes in reproductive success in Song Sparrows (Melospiza melodia) and Rufous-crowned Sparrows (Aimophila ruficeps) during wet years, while Littlefield (2009) speculated that Curve-billed Thrashers (Toxostoma curvirostre) avoid depredation from snakes by nesting earlier in the season during wet winters. To our knowledge, this is the first documentation of nest parasite driven variation in annual reproductive success during drought.

Working in coastal chaparral ecosystems, Morrison and Bolger (2002) suggested that reproductive success was limited by predators in wet years and limited by food in dry years. Central to their conclusion was the observation that their study species largely failed to nest during drought in 1999, an observation also made by Bolger and others (2005) for Rufous-crowned Sparrows and three additional study species during a severe drought in 2002.

In the Sonoran Desert, we found that Phainopepla will forego breeding during extreme drought, but that for other species, foregoing nesting is rare. Instead, Sonoran Desert species tended to delay nest initiation in a pattern that was linearly related to the severity of winter rainfall shortages. Thus, while food-resource limitation decreases reproductive success if species forego nesting completely, depredation and parasitism also reduce reproductive success during drought if species simply delay nest initiation. In the Sonoran Desert, we have found delayed nest initiation much more common than a complete cessation of nesting.

Delayed nesting exposes species to higher levels of depredation and parasitism that exist later in the breeding season and which are not experienced by early-nesting individuals in wet breeding seasons. Our 2010 experiment demonstrated that a nesting delay may result in significant decreases in reproductive success and reproductive output even in the midst of a wet breeding season.

It appeared that predator density increased on our study plots as the breeding season progressed. Female Brown-headed Cowbirds (which are both nest predators and nest parasites) were not present until mid-April. Anecdotally, we observed greater numbers of Greater Roadrunners (Geococcyx californianus) and Cactus Wrens (Campylorhynchus brunneicapillus) later in the season because of the presence of their recently fledged young, and we frequently observed what appeared to be family units of Cactus Wrens systematically hunting for gnatcatcher and Verdin nests in May, June, and July. In addition to avian predators, Littlefield (2009) and Morrison and Bolger (2002) provide arguments that snakes are more active later in the breeding season.

We also observed that the first broods of Black-tailed Gnatcatchers were more able to escape cowbird parasitism. Brown-headed Cowbirds have occupied southwestern North America only in the past 100-200 years (Laymon 1987, Lowther 1993), and it appears they have not yet adapted their breeding phenology to match the early-nesting species of the Mojave and Sonoran Deserts (van Riper, 2004). Assuming that female cowbirds began parasitizing nests immediately upon their arrival on our plots, gnatcatcher clutches completed by March 20 either would have fledged or nearly have fledged before losses to cowbird activity began. As days lost to drought delay accumulate, so accumulates the number of days the nest will be exposed to female cowbirds. This dynamic may play a significant role in the reproductive success of many other open-cup nesting species in southwestern North America, particularly residents, and perhaps short-distance migrants that appear to be most sensitive to droughtdelay.

It thus benefits species in the desert southwest to nest earlier in the season-particularly in systems without severe late winter storms - but in drought conditions, many bird species appear unable 
to do so. Perhaps food limitation inhibits early nest initiation in arid habitats during winter droughtthis is a topic that begs further research, given climate projections for the coming decades. While some species in the arid southwest forego nesting completely during drought, many others nest but with delay, a strategy that may produce diminished returns but which helps populations overcome loss to mortality. Additional pressure from cowbird parasitism may render a delayed nesting strategy untenable in the future for open-cup nesting species that are frequent cowbird hosts.

\section{Acknowledgments}

We wish to express our deep thanks to Dr. James Weigand and the Bureau of Land Management's California State Office for assistance with study design and funding of the California portion of this work. Paul Taillie and Leonard Warren provided invaluable assistance locating and monitoring nests in 2010. In addition, Stuart Johnston, Jora Rehm-Lorber, Karl Bardon, Eileen Mueller, Kelly Iknayan, Michelle Gibson, Caroline Ailanthus, James Campbell, and Kyle Horton located and monitored nests over several seasons. Lindsay Smythe and the Kofa National Wildlife Refuge assisted with nest monitoring and housing in 2009 and 2010. Drs. Bob Steidl, Courtney Conway, and William Mannan assisted with experimental design and manuscript review. We are grateful for funding provided by the California Off-Highway Motor Vehicle Recreation Division of California State Parks, the U.S. Geological Survey Ecosystem and Health Mission Areas, and the U.S. Fish and Wildlife Service via the Landscape Conservation Cooperative system. In particular, we thank Pattie Bright, George Lerom and David Lytle for their continued support of our research.

\section{References Cited}

American Ornithologists' Union, 1998, Check-list of North American birds, 7th ed.: Lawrence, Kansas, Allen Press, Inc., 829 p., http://checklist.aou.org/.

Anderson, A.H., and Anderson, A., 1973, The Cactus Wren: Tucson, Arizona, The University of Arizona Press, 226 p.

Beatley, J.C., 1969, Dependence of desert rodents on winter annuals and precipitation: Ecology, v. 50, p. 721-724.

Best, L.B., and Stauffer, D.F., 1980, Factors affecting nesting success in riparian bird communities: Condor, v. 82, p. 149-158.

Boag, P.T., and Grant, P.R., 1981, Intense natural selection in a population of Darwin's finches (Geospizinae) in the Galápagos: Science, v. 214, no. 4516, p. 82-85.

Bolger, D.T., Patten, M.A., and Bostock, D.C., 2005, Avian reproductive failure in response to an extreme climatic event: Oecologia, v. 142, p. 398-406.

Both, C., and Visser, M.E., 2001, Adjustment to climate change is constrained by arrival date in a longdistance migrant bird: Nature, v. 411, p. 296.

Brown, J.L., and Li, S., 1996, Delayed effect of monsoon rains influences laying date of a passerine bird living in an arid environment: Condor, v. 98, p. 879-884.

Brown J.L., Li, S., and Bhagabati, N., 1999, Long-term trend toward earlier breeding in an American bird-A response to global warming?: Proceedings of the National Academy of Sciences, v. 96, p. 5565-5569.

Burnham K.P., and Anderson, D.R., 2002, Model selection and multimodel inference-A practical information-theoretic approach, 2d ed.: New York, Springer-Verlag, 488 p. 
Chase, M.K., 2002, Nest site selection and nest success in a Song Sparrow population-The significance of spatial variation: Condor, v. 104, p. 103-116.

Chase, M.K., Nur, N., and Geupel, G.R., 2005, Effects of weather and population density on reproductive success and population dynamics in a Song Sparrow (Melospiza melodia) population-A long-term study: The Auk, v. 122, no. 2, p. 571-592.

Corman, T., and Wise-Gervais, C., 2005, Arizona breeding bird atlas: Albuquerque, New Mexico, University of New Mexico Press, 646 p.

Crick, H.Q.P., 2004, The impact of climate change on birds: Ibis, v. 146, supp. 1, p. 48-56.

Crick, H.Q.P., and Sparks, T.H., 1999, Climate change related to egg-laying trends: Nature, v. 399, p. 423.

Dunn, P.O., and Winkler, D.W., 1999, Climate change has affected the breeding date of Tree Swallows throughout North America: Proceedings of the Royal Society Biological Sciences, v. 266, no. 1437, p. 2487.

Esque, T.C., and Schwalbe, C.R., 2002, Alien annual plants and their relationships to fire and biotic change in Sonoran Desertscrub, chapter 13 in Tellman, B., ed., Invasive exotic species in the Sonoran region: Tucson, Arizona, Arizona-Sonora Desert Museum and The University of Arizona Press, $p$. 165-194.

Esque, T.C., Webb, R.H., Wallace, C.S.A., van Riper III, C., McCreedy, C., Smythe, L., 2013, Desert fires fueled by native annual forbs; The 2005 King Valley fire and its impacts on plant and bird communities in the Lower Sonoran Desert of Arizona: Southwestern Naturalist, v. 58 no. 3, p. 223233, http://dx.doi.org/10.1894/0038-4909-58.2.223

Farquhar, C.C. and Ritchie K.L., 2002, Black-tailed Gnatcatcher (Polioptila melanura), in Poole, A., ed., The birds of North America: Ithaca, New York, Cornell Lab of Ornithology, accessed Dec. 16, 2015, at http://bna.birds.cornell.edu/bna/species/690.

Grant, P.R., and Grant, B.R., 1987, The extraordinary El Niño event of 1982-83-Effects on Darwin's finches on Isla Genovesa, Galápagos: Oikos, v. 49, no. 1, p. 55-66.

Grant, T.A., Shaffer, T.L., Madden, E.M., and Pietz, P.J., 2005, Time-specific variation in passerine nest survival-New insights into old questions: The Auk, v. 122, no. 2, p. 661-672.

International Bird Census Committee, 1970, An international standard for a mapping method in bird census work recommended by the International Bird Census Committee: Audubon Field Notes, v. 24, p. 722-726.

Jaksic, F.M., Silva, S.I., Meserve, P.L., and Gutierrez, J.R., 1997, A long-term study of vertebrate predator responses to an El Niño (ENSO) disturbance in western South America: Oikos, v. 78, p. 341-354.

Johnson, D.H., 1979, Estimating nest success_-The Mayfield method and an alternative: The Auk, v. 96, p. 651-661.

Johnson, M.J., van Riper, C., III, and Pearson, K.M., 2002, Black-throated Sparrow (Amphispiza bilineata), in Poole, A., ed., The birds of North America: Ithaca, New York, Cornell Lab of Ornithology, accessed December 5, 2015, at http://bna.birds.cornell.edu/bna/species/637/ articles/introduction.

Latta, M.J., Beardmore, C.J.and Corman T.E., 1999, Arizona Partners in Flight Bird Conservation Plan, ver. 1.0: Phoenix, Arizona Game and Fish Department, Nongame and Endangered Wildlife Program Technical Report 142.

Laymon, S.A., 1987, Brown-headed Cowbirds in California-Historical perspectives and management opportunities in riparian habitats: Western Birds, v. 18, p. 63-70. 
Littlefield, C.D., 2009, Curve-billed Thrasher reproductive success after a wet winter in the Sonoran Desert of Arizona: Western Birds, v. 40, v. 3, p. 234-236.

Lowther, P.E., 1993, Brown-headed Cowbird (Molothrus ater), in Poole, A., ed., The birds of North America: Ithaca, New York, Cornell Lab of Ornithology, accessed Dec. 16, 2015, at http://bna.birds.cornell.edu/bna/species/047.

Martin, T.E., and Geupel, G.R., 1993, Nest monitoring plots-Methods for locating nests and monitoring success: Journal of Field Ornithology, v. 64, p. 507-519.

Martin, T.E., Paine, C., Conway, C.J., Hochachka, W.M., Allen, P., and Jenkins, W., 1997, The Breeding Biology Research and Monitoring Database (BBIRD) Field Protocol: Missoula, University of Montana Cooperative Unit, accessed December 8, 2015, http://www.umt.edu/bbird/protocol/.

Mayfield, H., 1975, Suggestions for calculating nest success: Wilson Bulletin, v. 87, p. 456-466.

McCreedy, C., Pitkin, M., Duberstein, J., Kreitinger, K., and DiGaudio, R., 2009, Desert bird conservation plan, ver. 1.0: California Partners in Flight, http://www.prbo.org/calpif/htmldocs/desert.htm.

McCreedy, C., and van Riper, C., III, 2015, Drought-caused delay in nesting of Sonoran Desert birds and its facilitation of parasite- and predator-mediated variation in reproductive success: The Auk, v. 132, no. 1, p. 235-247.

Morrison, S.A., and Bolger, D.T., 2002, Variation in a sparrow's reproductive success with rainfallFood and predator-mediated processes: Oecologia, v. 133, p. 315-324.

National Oceanic and Atmospheric Administration, 2015, Climate narratives of the state: Reno, Nevada, Western Regional Climate Center, accessed February 2, 2015, at http://www.wrcc.dri.edu/narratives/nevada/.

National Weather Service, 2010, Phoenix, AZ, http://www.wrh.noaa.gov/psr/climate/annualMonthly RcdsPHX.php?wfo=psr, accessed December 7, 2015.

Phillips, S.J., and Wentworth Comus, P., eds., 1999, A natural history of the Sonoran Desert: Tucson, Arizona, Arizona-Sonora Desert Museum Press, 628 p.

Preston, K.L., and Rotenberry, J.T., 2006, The role of food, nest predation, and climate in timing of Wrentit reproductive activities: Condor, v. 108, p. 832-841.

Ralph, C.J., Geupel, G.R., Pyle, P., Martin, T.E., and DeSante, D.F., 1993, Handbook of field methods for monitoring landbirds: Albany, California, U.S. Department of Agriculture, Forest Service, Pacific Southwest Research Station, General Technical Report PSW-GTR-144-www, 41 p. [Also available at http://www.fs.fed.us/psw/publications/documents/psw_gtr144/psw_gtr144.pdf.]

Sawyer, J.O., and Keeler-Wolf, T., 2009, A Manual of California Vegetation, 2d ed.: Berkeley, California, California Native Plant Society, 1300 p.

Seager, R., Mingfang, T., Held, I., Kushnir, Y., Lu, J., Vecchi, G., Huang, H., Harnik, N., Leetmaa, A., Lau, N., Li, C., and others, 2007, Model projections of an imminent transition to a more arid climate in southwestern North America: Science, v. 316, p. 1181.

Shaffer, T.L., 2004, A unified approach to analyzing nest success: The Auk, v. 109, p. 585-593.

Shaffer, T.L., and Thompson, F.R., III, 2007, Making meaningful estimates of nest survival with modelbased methods: Studies in Avian Biology, v. 34, p. 84-95.

Sullivan, B.L., Wood, C.L., Iliff, M.J., Bonney, R.E., Fink, D., and Kelling, S., 2009, eBird-A citizenbased bird observation network in the biological sciences: Biological Conservation, v. 142, p. 22822292.

van Riper, C., III, 2004, Brown-headed Cowbird parasitism of the Black-throated Sparrow in Central Arizona: Journal of Field Ornithology, v. 75, no. 3, p. 303-311. 
Webster, M.D., 1999, Verdin (Auriparus flaviceps), in Poole, A., ed., The birds of North America: Ithaca, New York, Cornell Lab of Ornithology, accessed Dec. 16, 2015, at http://bna.birds.cornell.edu/bna/species/470.

Whitford, W.G., and Creusere, F.M., 1977, Seasonal and yearly fluctuations in Chihuahuan Desert lizard communities: Herpetologica, v. 33, no. 1, p. 54-65. 


\title{
Chapter 2-Avian Response to Fire at Kofa National Wildlife Refuge in the Sonoran Desert
}

\begin{abstract}
Fire has historically been an infrequent event in the Sonoran Desert. In 2005, a human-caused, 9,000-hectare fire in the King Valley spread from the Yuma Proving Ground into the Kofa National Wildlife Refuge, Arizona. More than 80 percent of xeroriparian live cover within the fire's perimeter was lost and was slow to recover: in 2009 and 2010, we found that burned sites still held significantly fewer migrant bird species and fewer total birds detected than nearby, unburned sites. We observed fewer than half the number of birds at burned sites compared to nearby unburned stations among 11 of 19 breeding species; four breeding species found at unburned control sites were still completely absent from burned sites 5 years after the fire. Only two breeding species, the Loggerhead Shrike (Lanius

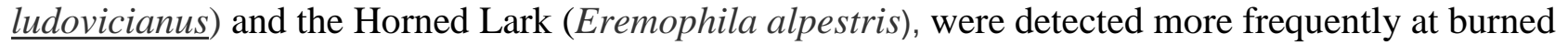
than at unburned sites. Among nonbreeding migrants, across all foraging guilds, we observed fewer than half the number of birds at burned sites compared to nearby unburned sites. Our study demonstrates that fire in Sonoran Desert ecosystems can have long-term consequences to the structure of breeding and migrant bird communities.
\end{abstract}

\section{Introduction}

Fire frequency and extent have increased across western North America in recent decades (Saab and Powell, 2005; Bukowski and Baker, 2013). In recognition of this new dynamic, it is important to properly assess the effects of fire in avian communities, particularly in desert ecosystems. Bird species respond to fire differently, with the direction and strength of response determined by the particular species and habitat being studied (Saab and Powell, 2005). Different avian responses have been attributed to the severity and the patchiness of the burn (Knick and others, 2005), seed sources and response time of plants available to recolonize a site (Bock and Block, 2005), and relative value of colonizing plants as cover and forage for birds (Bock and Block, 2005). In spite of this increasing body of work, fire effects on bird communities in the lower Sonoran Desert remain largely unknown.

Historically, fires in the Sonoran and Mojave Deserts were infrequent, particularly at low elevations, where few plants and light fuel loads prevented fire spread (McLaughlin and Bowers, 1982; Brooks and Matchett, 2006). This infrequent fire regime began to change by the end of the 20th century, as invasive annuals such as red brome (Bromus sp.) and Mediterranean grasses (Schismus sp.) increased in abundance and extent across the region. The new persistence and ubiquity of these annuals fueled fires ignited by lightning and by a rapidly increasing human population (Brooks and Matchett, 2006).

In a region of historically low fire frequency, many of the Sonoran Desert perennial plant species are not fire-adapted (Abella, 2009). In particular, lower elevation arborescent species (for example, mesquites [Prosopis sp.], paloverde [Parkinsonia sp.], ironwoods [Olneya tesota]), and columnar cacti such as saguaro (Carnegiea gigantea) and organ pipe (Stenocereus thurber) are easily killed by fires and slow to recolonize after burns (Humphrey, 1949). Loss of these slow-growing canopy species to fire could potentially have negative and severe impacts on the bird populations that depend on these 
woodland and cacti species for foraging, nesting, and cover (Russell and Monson, 1998; Bock and Block, 2005).

The King Valley fire of September 2005 was caused by incendiary weapons testing on the Yuma Proving Ground, a military testing and training facility in southwestern Arizona (Esque and others, 2013). The fire spread northward into the Kofa National Wildlife Refuge, ultimately burning an estimated total of 9,975 hectares. Between 81 percent and 91 percent of live perennial cover was consumed in the fire, leaving large areas devoid of trees and shrubs. We build upon the work of Esque and others (2013) and compare species richness and abundance for both breeding and non-breeding migrant species four and five years after the King Valley fire.

\section{Methods}

\section{Study Sites}

The King Valley is in Yuma County, Arizona, and includes the southern half of the Kofa National Wildlife Refuge (Kofa NWR) $\left(33.19^{\circ}\right.$ N. and $114.02^{\circ}$ W.; fig. 2.1). The valley drains southward from the Kofa NWR into the Yuma Proving Ground (YPG), and study sites within and outside the King Valley burn averaged roughly $300 \mathrm{~m}$ above sea level in elevation. Xeroriparian corridors that drain the valley are dominated by woodland species including blue paloverde (Parkinsonia florida), ironwood (Olneya tesota), velvet mesquite (Prosopis velutina), and yellow paloverde (Parkinsonia microphylla). Mature saguaros (Carnegiea gigantean) are found at lower elevations in King Valley but are uncommon. Upland vegetation surrounding xeroriparian corridors is dominated by creosote (Larrea tridentata) and white bursage (Ambrosia dumosa). 


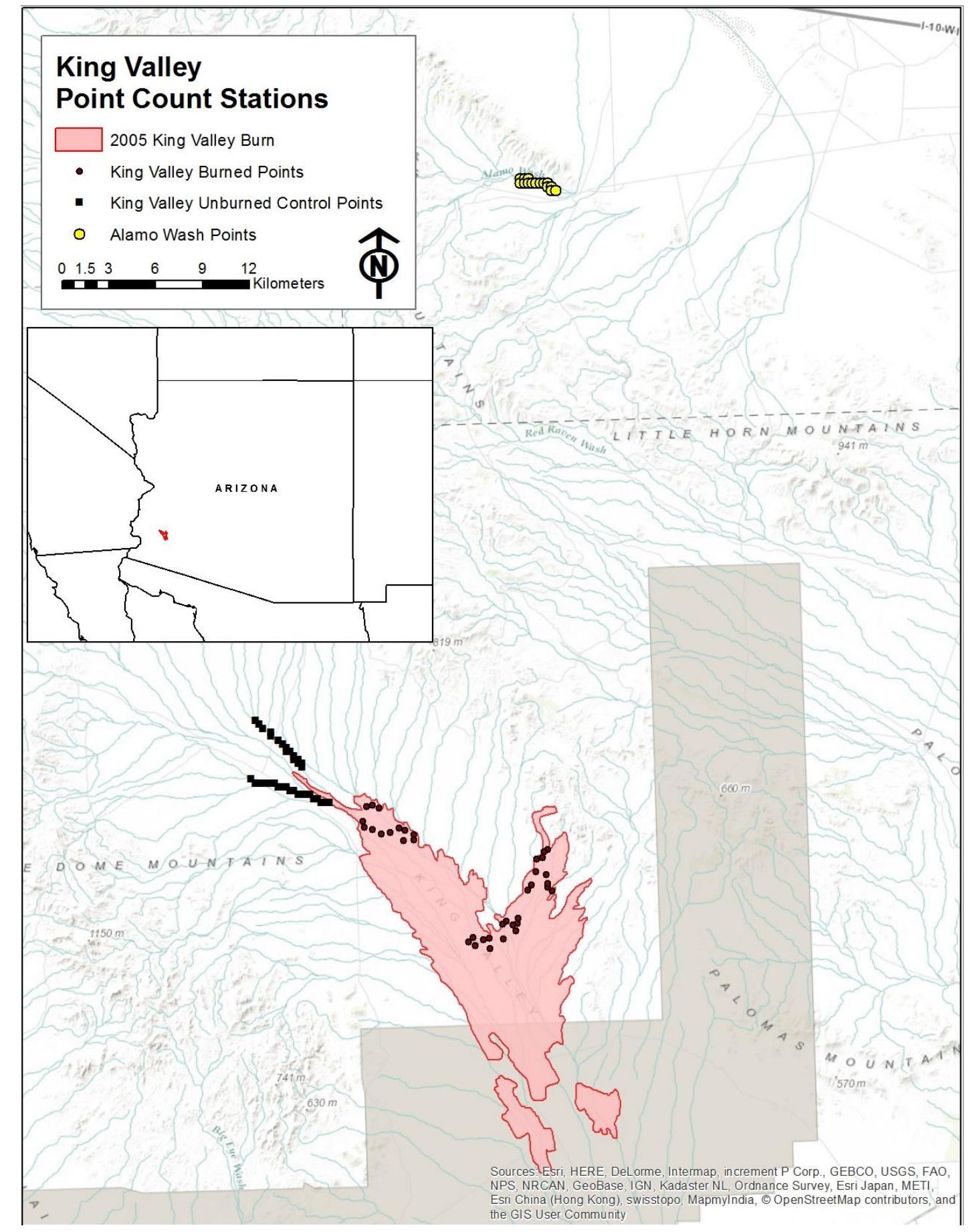

Figure 2.1. Map of study sites in Kofa National Wildlife Refuge, Yuma and La Paz Counties, Arizona. Fire is marked by red polygon in both map and in state-scale insert beneath legend. Yuma Proving Ground is brownshaded polygon to east of burn extent and through southern quarter of burn. Yuma-La Paz County Line (Yuma to south) denoted by dashed east-west line through Little Horn Mountains. 


\section{Point Count Surveys}

We randomly selected 37 xeroriparian points that were paired from a set of previouslyestablished U.S. Geological Survey (USGS) study sites within the 2005 King Valley burn (Esque and others, 2013). We also used a UTM-based grid of systematic random points to identify point count stations at 37 unburned control points in King Wash. We then conducted avian point count surveys on the 74 burned and unburned control points in the springs of 2009 and 2010 (fig. 2.1).

The King Valley wash complex is a multi-braided wash system, and its largest channel reaches were burned in the 2005 fire. Thus, our 37 unburned control points had to be relegated to narrower wash corridors than the larger channels that lost vegetation cover in the 2005 fire. To provide additional comparison of bird abundance and richness parameters between burned and unburned points in washes of comparable width, we also conducted point count surveys at 37 unburned points at Alamo Wash $\left(33.52^{\circ} \mathrm{N}\right.$. and $113.83^{\circ}$ W.) in 2009 and 2010 (fig. 2.1). Alamo Wash also lies within the Kofa NWR, 40 $\mathrm{km}$ to the north of the King Valley fire. Alamo Wash points averaged $500 \mathrm{~m}$ above sea level in elevation.

We conducted 5-minute variable circular plot point counts at all stations (Reynolds and others, 1980), following standards recommended by Ralph and others $(1993,1995)$. We used a Leica Rangefinder LRF800 to measure distances to detections, and we excluded detections greater than $100 \mathrm{~m}$ and "flyovers" in analyses. We recorded all birds that were heard or seen during the 5-minute count at each station during the breeding community's peak breeding season (between March 15 and May 7). We completed two counts at each station, at least 13 days apart.

To minimize observer bias and time of day effects on detection rates, we rotated observers at each station visit and stations were surveyed in opposite order. We conducted surveys in the morning, beginning no earlier than 30 minutes before sunrise and ending no later than 4 hours after sunrise, and did not survey in windy (>15 kmph) or rainy conditions. We also recorded all observations of breeding behavior (for example, nesting material carry) and located nests during counts and while walking between survey points.

We identified breeders as species known to breed in Sonoran Desert xeroriparian vegetation (Russell and Monson, 1998; McCreedy, 2010). We categorized non-breeders as species detected during surveys that did not breed during a long-term study within many other washes in the region (McCreedy, 2010).

At our burned sites, we did not accrue a sufficient number of detections to generate detection curves and density estimates, falling well short of the minimum of 40 detections for even the most common species in 2009 and in 2010 (Buckland and others, 2001). Because our objective was to examine differences in bird species richness and relative abundance between burned and unburned stations, not to generate precise abundance estimates, we utilized a relative index of abundance for our count data.

To calculate this index of abundance, we calculated the mean number of individuals per point count station, summed over the two visits. We assumed that detection rates between burned (very low vegetation cover) and unburned stations (low vegetation cover) would be similar, and that our index of abundance is an underestimate of true abundance. We calculated species richness for each point count station using all detections within $100 \mathrm{~m}$, summed over two visits. We calculated species richness and index of abundance separately for breeding species and nonbreeding migrants. 


\section{Point Count Vegetation Assessments at Burned and Unburned Points}

We used the relevé method described in Mueller-Dombois and Ellenberg (1974) and modified for birds as in Ralph and others (1993) to measure percent cover, by height category, for each species of perennial plant equal to or greater than $0.50 \mathrm{~m}$ in height. Plots were $50 \mathrm{~m}$ radius circles centered on each point count station. Height categories were "herb" $(0.01-0.49 \mathrm{~m})$, "shrub" $(0.5-4.9 \mathrm{~m})$ and "tree" ( $\geq 5$ $\mathrm{m})$. We measured canopy radius of each perennial plant, then categorized each measured plant by radius $(.25 \mathrm{~m}, .50 \mathrm{~m}, 1 \mathrm{~m}, 1.5 \mathrm{~m}, 2 \mathrm{~m}, 2.5 \mathrm{~m}, 3 \mathrm{~m}, 3.5 \mathrm{~m}, 4 \mathrm{~m}, 5 \mathrm{~m}$, and $6 \mathrm{~m})$, and calculated cover directly in order to increase measurement precision.

We measured 100-m line-intercept transects in a 2-m-wide belt along one edge of the wash channel (described in Esque and others, 2013, and following Elzinga and others, 1998) to quantify vegetation cover at burned points in 2009. For the burned xeroriparian transects, we selected a section of the wash that included continuous floodplain uninterrupted by intersecting tributaries. At each transect start point, we used a coin toss to determine which side of the wash to place the transect. An iron bar (rebar) was placed at the edge of the identifiable channel where the unconsolidated gravel and bare ground met with established soils. A 100-m tape was used to delineate the contour of the wash and soil bank, starting at $0 \mathrm{~m}$ running down slope to $100 \mathrm{~m}$, where we placed a second rebar. We recorded GPS coordinates for the beginning and end points of all transects.

\section{Results}

In King Valley, we found significantly higher breeding species richness at unburned control sites than at burned sites in both 2009 (two-sided $p$-value $<0.0001, t_{72}=-8.90$, DIFF C.I. $=3.21-5.07$ ) and in 2010 (two-sided $p$-value $<0.0001, t_{72}=-8.18$, DIFF C.I. $=2.81-4.61$ ), with breeding species richness at unburned points averaging more than double the richness values found at burned points (fig. 2.2A). We also found a significantly higher index of abundance of breeding species at unburned sites than at burned sites in both 2009 (two-sided $p$-value $<0.0001, t_{72}=-6.45$, DIFF C.I. $=4.89-9.27$ ) and in 2010 (two-sided $p$-value $<0.0001, t_{72}=-7.13$, DIFF C.I. $=5.43-9.65$ ). We typically detected nearly three times as many breeding individuals at unburned than at burned points in King Valley.

Comparing unburned King Valley points to points in Alamo Wash, we found significantly higher breeding-species richness at Alamo Wash than at unburned points in King Valley in both 2009 (two-sided $p$-value $<0.0001, t_{72}=-5.37$, DIFF C.I. $=1.39-3.03$ ) and in 2010 (two-sided $p$-value $<0.0001$, $t_{72}=-5.01$, DIFF C.I. $=1.37-3.17$; fig 2.2A). We also found a significantly higher index of abundance of breeding species at Alamo Wash than at unburned King Valley points in 2009 (two-sided $p$-value $<0.0001, t_{72}=-9.57$, DIFF C.I. $=7.76-11.86$ ) and in 2010 (two-sided $p$-value $<0.0001, t_{72}=-6.39$, DIFF C.I. $=4.95-9.43)$.

Among nonbreeding migrants, we also found significantly higher species richness at unburned sites in King Valley than at burned sites in both 2009 (two-sided $p$-value $<0.0001, t_{72}=-5.20$, DIFF C.I. $=$ $0.98-2.20$ ) and in 2010 (two-sided $p$-value $<0.0001, t_{72}=-6.80$, DIFF C.I. $=1.49-2.73$ ). Nonbreeding migrant species richness averaged three times higher at unburned than at burned points in King Valley (fig. 2.2B).

In addition, we also found a significantly higher index of abundance of nonbreeding migrants at unburned sites in the King Valley than at burned sites in 2009 (two-sided $p$-value $<0.0001, t_{72}=-5.39$, DIFF C.I. $=3.78-8.22$ ) and also in 2010 (two-sided $p$-value $=0.0037, t_{72}=-2.76$, DIFF C.I. $=0.85-5.27$ ). Relative abundance of nonbreeding migrants averaged two to five times higher at unburned points in the King Valley than at burned points. 
A comparison of nonbreeding migrant species richness and abundance at Alamo Wash and unburned points in King Valley produced mixed results. Comparing unburned King Valley points to points in Alamo Wash, we found significantly higher nonbreeding migrant species richness at Alamo Wash than at unburned points in King Valley in 2009 (two-sided $p$-value $=0.005, t_{72}=-3.63$, DIFF C.I. $=$ $0.67-2.31$ ), but the pattern was reversed in 2010 (two-sided $p$-value $=0.002, t_{72}=3.26$, DIFF C.I. $=0.44$ 1.84), fig 2.2A). There was not a significant difference in nonbreeding migrant species abundance in either 2009 (two-sided $p$-value $=0.16, t_{72}=-1.41$, DIFF C.I. $=-0.84-4.84$ ) nor in 2010 (two-sided $p$-value $=0.16, t_{72}=1.39$, DIFF C.I. $\left.=-0.65-3.63\right)$ between Alamo Wash and unburned King Valley points.

There were significant differences in the number of detections by breeding species and year (table 2.1). Of 19 breeding species that we detected, 11 were observed at least 50 percent less often at burned stations compared to unburned stations in the King Valley. Four species (White-winged Dove [Zenaida asiatica], Red-tailed Hawk [Buteo jamaicensis], Gila Woodpecker [Melanerpes uropygialis], and Abert's Towhee [Pipilo aberti]) were found only at unburned stations in 2010. Only two species (Horned Lark [Eremophila alpestris] and Loggerhead Shrike, [Lanius ludovicianus]) were more common at burned sites. 

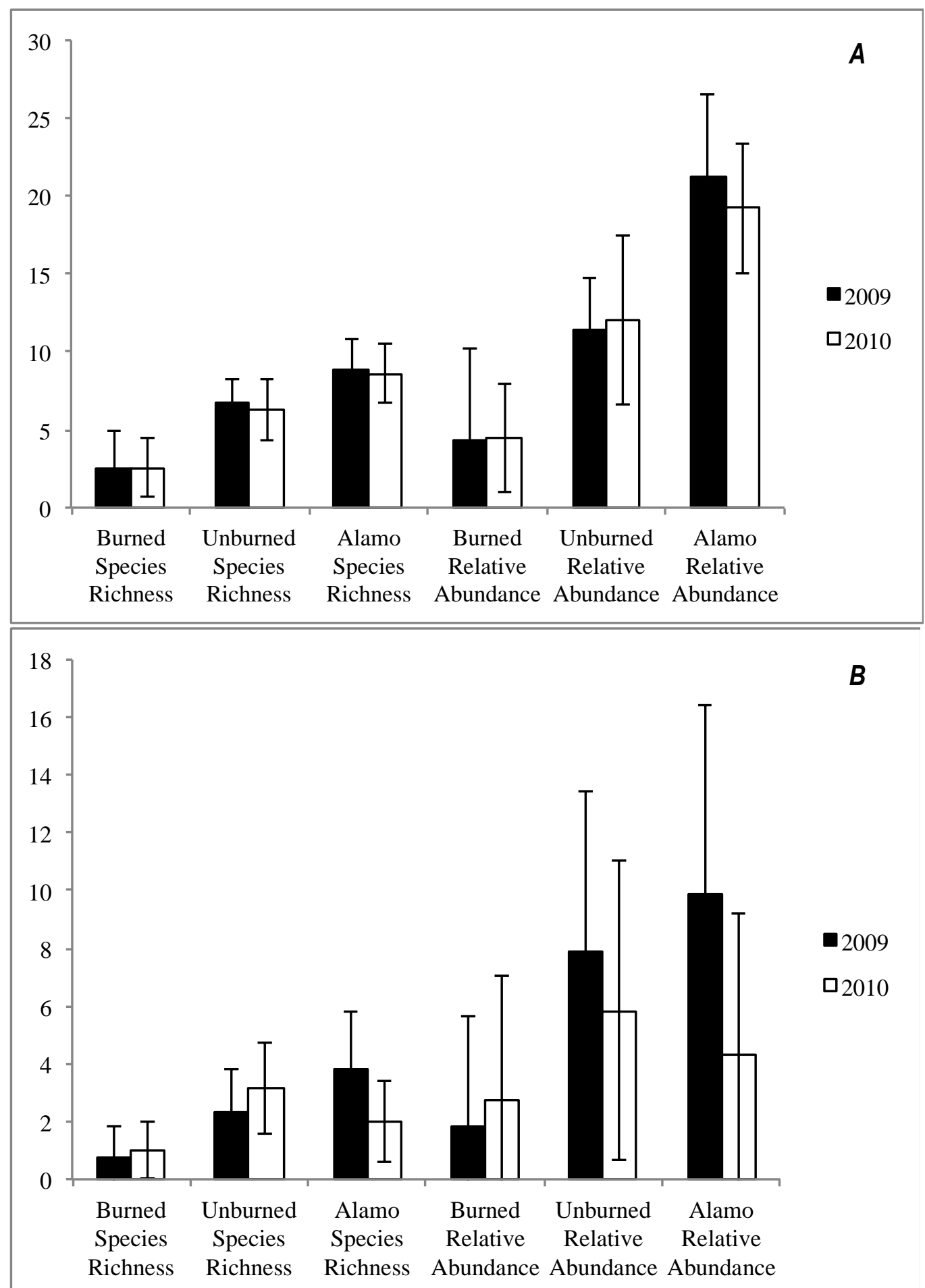

Figure 2.2. $A$, Breeding species richness and relative abundance and $B$, Non-breeding species richness and relative abundance (both plots organized by site type, with 1-sigma standard deviation bars) at burned sites in King Valley, at unburned sites in King Valley, and at control sites in Alamo Wash, 2009 and 2010 ( $n=37$ for each year). Only detections for $<100 \mathrm{~m}$ (summed over two visits) from the point are included. Relative abundance estimates should be considered underestimates of true abundance. 
Table 2.1. Number of detections by breeding species at 37 burned and 37 unburned stations in the King Valley Wash complex, Yuma County, Arizona.

[The King Valley sites burned in 2005, and these data represent 4- and 5-year post-fire conditions. Percent difference is the percent of detections at burned sites relative to detections at nearby unburned sites for that species and year. Species ranked according to strength of decrease in numbers between unburned and burned. Only species detected in both 2009 and 2010 are listed]

\begin{tabular}{|c|c|c|c|c|c|c|}
\hline & \multicolumn{3}{|c|}{2009} & \multicolumn{3}{|c|}{2010} \\
\hline & Unburned & Burned & Percent difference & Unburned & Burned & Percent difference \\
\hline \multicolumn{7}{|c|}{ Extirpated } \\
\hline White-winged Dove (Zenaida asiatica) & 4 & 0 & -100 & 4 & 0 & -100 \\
\hline Red-tailed Hawk (Buteo jamaicensis) & 2 & 0 & -100 & 1 & 0 & -100 \\
\hline Gila Woodpecker (Melanerpes uropygialis) & 1 & 0 & -100 & 2 & 0 & -100 \\
\hline Abert's Towhee (Pipilo aberti) & 2 & 1 & -50 & 6 & 0 & -100 \\
\hline \multicolumn{7}{|c|}{ Strong decrease } \\
\hline Black-tailed Gnatcatcher (Polioptila melanura) & 42 & 6 & -86 & 36 & 2 & -94 \\
\hline Phainopepla (Phainopepla nitens) & 69 & 11 & -85 & 89 & 11 & -88 \\
\hline Verdin (Auriparus flaviceps) & 74 & 19 & -74 & 42 & 6 & -86 \\
\hline Ash-throated Flycatcher (Myiarchus cinerascens) & 45 & 11 & -76 & 21 & 8 & -62 \\
\hline Gambel's Quail (Callipepla gambelii) & 72 & 33 & -54 & 78 & 26 & -67 \\
\hline Black-throated Sparrow (Amphispiza bilineata) & 23 & 10 & -56 & 50 & 27 & -46 \\
\hline Mourning Dove (Zenaida macroura) & 33 & 14 & -58 & 27 & 13 & -52 \\
\hline \multicolumn{7}{|c|}{ Moderate Decrease } \\
\hline Northern Mockingbird (Mimus polyglottos) & 15 & 13 & -13 & 35 & 28 & -20 \\
\hline Crissal Thrasher (Toxostoma crissale) & 10 & 0 & -100 & 2 & 2 & 0 \\
\hline \multicolumn{7}{|c|}{ Mixed } \\
\hline Cactus Wren (Campylorhynchus brunneicapillus) & 15 & 13 & -13 & 2 & 4 & 100 \\
\hline Costa's Hummingbird (Calypte costae) & 5 & 0 & -100 & 5 & 5 & 0 \\
\hline House Finch (Haemorhous mexicanus) & 5 & 8 & 60 & 3 & 0 & -100 \\
\hline Ladder-backed Woodpecker (Picoides scalaris) & 3 & 0 & -100 & 2 & 1 & 50 \\
\hline \multicolumn{7}{|c|}{ Increase } \\
\hline Horned Lark (Eremophila alpestris) & 0 & 5 & $\infty$ & 4 & 9 & 125 \\
\hline Loggerhead Shrike (Lanius ludovicianus) & 2 & 14 & 700 & 1 & 9 & 900 \\
\hline
\end{tabular}


Table 2.2. Number of detections by nonbreeding species at 37 burned and 37 unburned stations in the King Valley wash complex, Yuma County, Arizona.

[The King Valley sites burned in 2005, data represent 4- and 5-year post-fire conditions. Percent difference is the percent of detections at burned sites relative to detections at nearby unburned sites for that species and year. Species listed in taxonomic order and grouped by guild. Percent differences only summarized for guilds, due to generally low sample sizes at species level. Raptor detections $(n=2)$ not included]

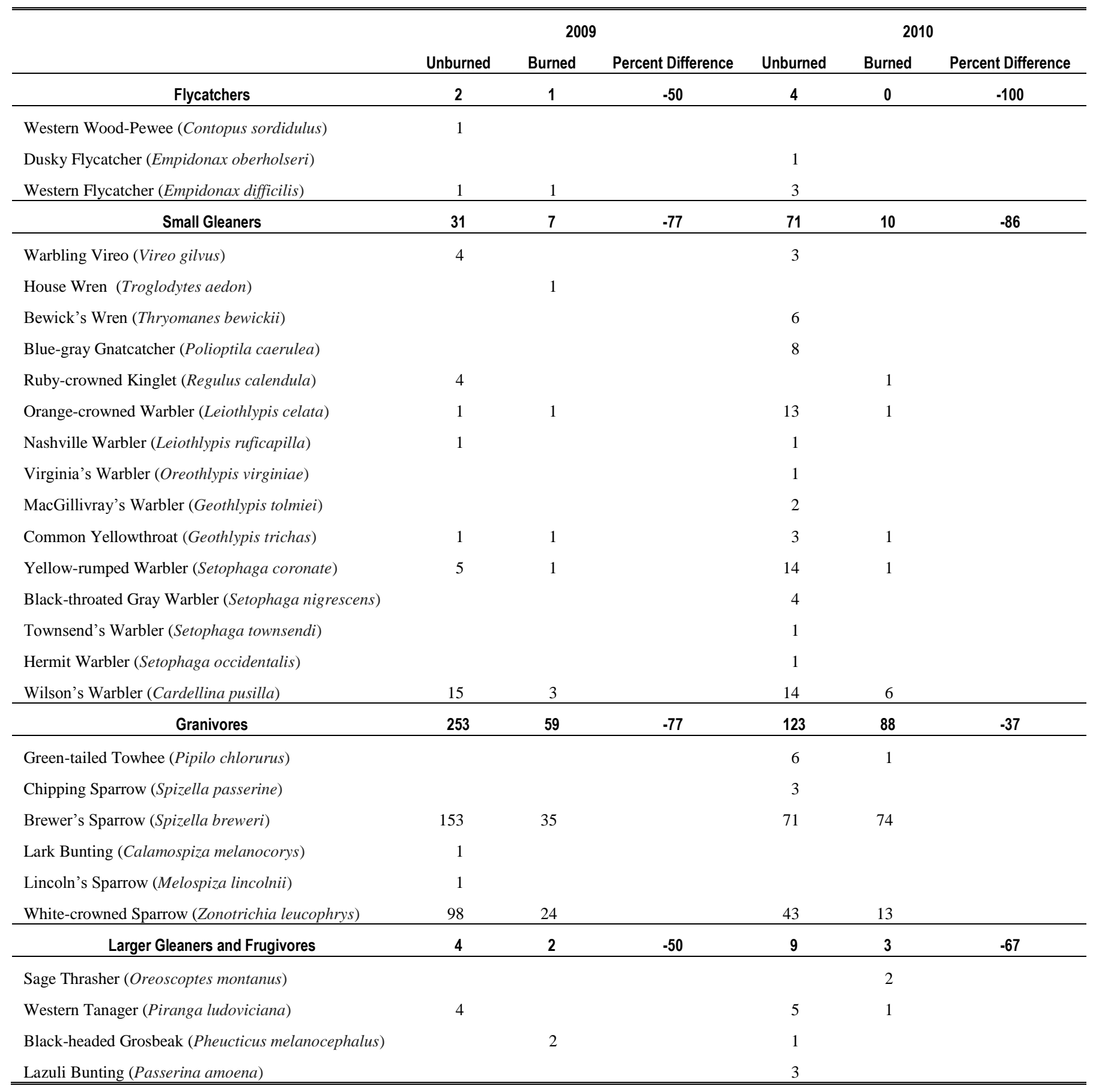


We detected higher numbers of nonbreeding migrants in unburned versus burned sites across all foraging guilds in both 2009 and 2010. Flycatchers, small gleaners, and larger gleaners, and frugivores are typically found in arborescent vegetation such as paloverdes, ironwoods, and mesquites, although we occasionally found them foraging in desert shrubs such as creosote and wolfberry (Lycium sp.). Granivores are typically found foraging on the ground in annual vegetation. We found substantial differences (typically -50-100 percent) in the number of detections at burned stations versus unburned stations for all guilds in 2009 and 2010.

Nests of only eight species were found during surveys within the area affected by fire (table 2.3).

Table 2.3. Nests located in 2009-2010 within the area affected by the King Valley burn.

[UTM coordinates (easting, northing) in NAD 83, zone 12. Concealment refers to the plant species providing primary cover to the nest, $\%$ alive is an estimate of the amount of the substrate's canopy that was alive when the nest was found]

\begin{tabular}{|c|c|c|c|c|c|c|}
\hline Species & Easting & Northing & Nest Stage & Substrate & Concealment & $\%$ alive \\
\hline Gambel's Quail & 236157 & 3668514 & Eggs & ground & i. E. farinosa & $\mathrm{n} / \mathrm{a}$ \\
\hline Ash-throated Flycatcher & 235954 & 3669177 & Building & O. tesota & O. tesota & 0 \\
\hline \multirow[t]{2}{*}{ Loggerhead Shrike } & 235386 & 3668093 & Eggs & O. tesota & O. tesota & 70 \\
\hline & 234007 & 3664773 & Eggs & O. tesota & O. tesota & 30 \\
\hline Phainopepla & 231299 & 3664030 & Eggs & P. florida & P. florida & 98 \\
\hline \multirow[t]{2}{*}{ Bendire's Thrasher } & 234057 & 3664669 & Eggs & O. tesota & O. tesota & 80 \\
\hline & 235820 & 3666635 & Young & O. tesota & O. tesota & 96 \\
\hline \multirow[t]{2}{*}{ Northern Mockingbird } & 236065 & 3666678 & Young & P. microphylla & P. microphylla & 87 \\
\hline & 233988 & 3663692 & Eggs & Lycium & Lycium & 95 \\
\hline
\end{tabular}

Similar to the findings of Esque and others (2013), we found higher perennial cover at unburned than at burned point count stations in King Valley (fig. 2.3). Mean vegetation cover recorded by Esque and others (2013) at unburned sites was likely higher than our estimates of mean vegetation cover due to differences in methodology, as their transects followed only wash edges, which are generally the most vegetated portion of xeroriparian habitats. In contrast to the study by Esque and others (2103), our plots were circular and not linear, thus they invariably included nonvegetated sections of the wash channel as well as upland habitat that existed within $50 \mathrm{~m}$ of the point. Our mean vegetation cover estimates at burned sites are likely overestimates of living cover, because (1) dead, standing vegetation (like ironwood, the most likely species to avoid incineration in the fire) was counted as cover in our transect surveys, and (2) a substantial amount of charred plants recorded on the 2007 vegetation transect surveys conducted by Esque and others (2013) were expected to die by the time our bird surveys occurred in 2009 and 2010. 


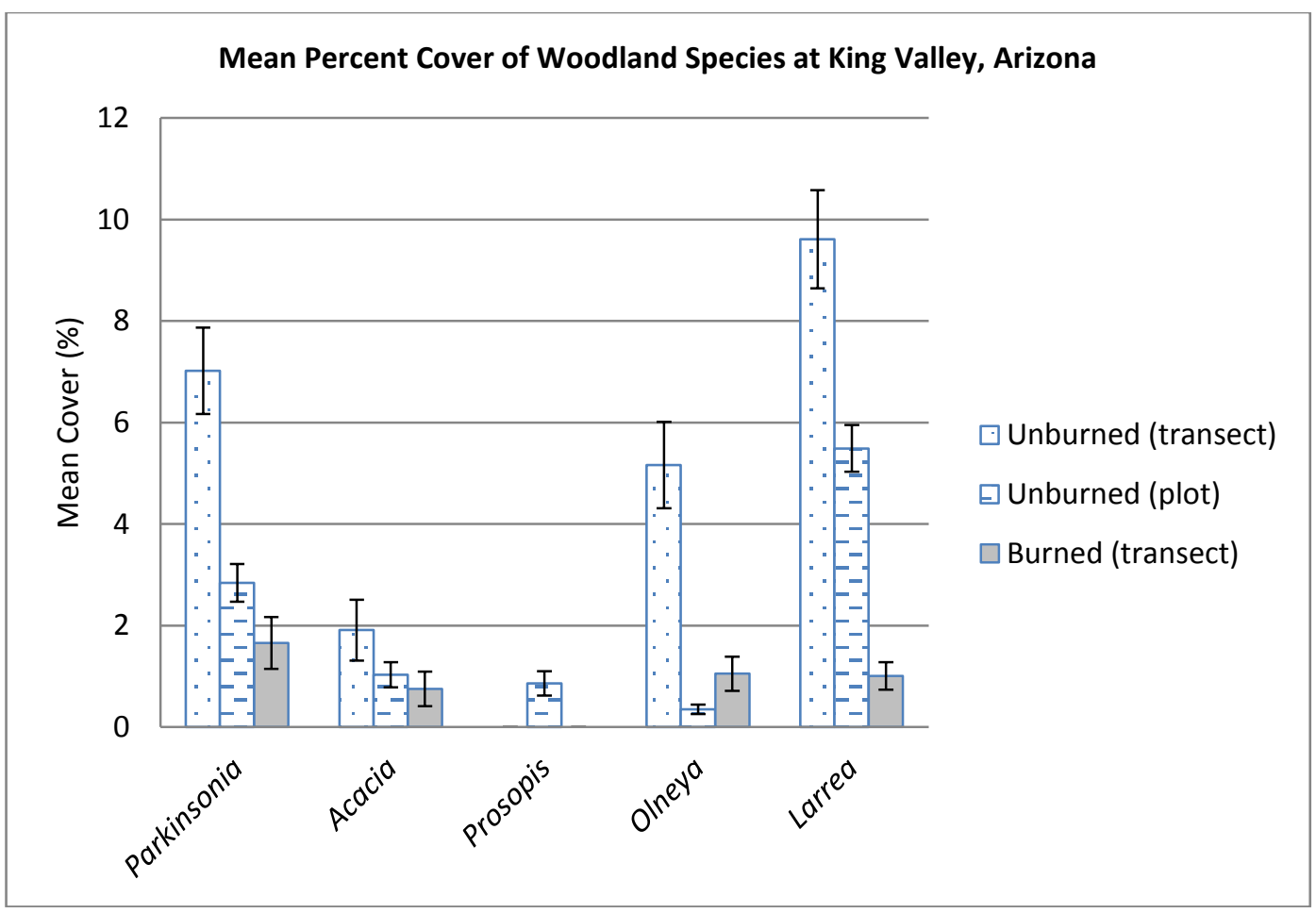

Figure 2.3. Mean percent cover by woodland species (with standard error bars) at unburned and burned xeroriparian study sites in King Valley, Arizona. Transect estimates measured along wash channel's edge. Plot estimates were from circular plots centered on point-count stations (50 $\mathrm{m}$ radius). Parkinsonia includes Blue Paloverde and Yellow Paloverde combined, though plot estimates found over 95 percent of Parkinsonia cover to be Blue Paloverde.

\section{Discussion}

More than 4.5 years after the 2005 King Valley fire, burned xeroriparian areas still supported significantly fewer birds than found in nearby, unburned xeroriparian areas. Burned points typically supported less than half the species richness and relative abundance as unburned points. This pattern held across multiple guilds of birds, regardless of breeding or nonbreeding status.

While our data from unburned points provide an indication of the numbers and diversity of birds lost to the King Valley wash complex after the fire, it is likely that this underestimates the loss, because of the unburned points' geographic location in the watershed. In previous work throughout the Lower Colorado subdivision of the Sonoran Desert, we have found that wider washes of high woodland cover tend to support high numbers and diversity of birds (McCreedy, 2010). We lack prefire vegetation data for the King Valley, but aerial photographs suggest that the King Valley fire disproportionately eliminated much of the widest and most heavily vegetated wash reaches (Esque and others, 2013). This relegated our post-fire surveys of unburned areas to higher elevation wash channels of narrower width, reaches likely to hold less woodland vegetation and thus fewer birds. Previous work found the nearby Alamo Wash to support the highest abundance and species richness of several washes surveyed in southwestern Arizona (Esque and others, 2013), and we have included results from the Alamo Wash in figures $2.2 A$ and $2.2 B$ to present an upper-bound estimate to the abundance and richness of species that may have been found in the King Valley prior to the 2005 fire.

Moreover, we found very few nests within the perimeter of the burned area, and these nests were generally easy to find and often built in one of the few standing trees in the area. Hence, many of the 
breeding individuals we detected in burned areas during our point counts may not have been pairedthey may have been prospecting individuals without nests, or roaming territorial individuals nesting beyond the burn's periphery.

Notably, the only breeding species counted more often at burned sites then unburned ones were Horned Lark, a ground nester accustomed to barren habitats without tree or shrub cover (Beason, 1995) and Loggerhead Shrike, a species associated with open scrubland that occasionally uses trees for nesting (Yosef, 1996). Horned Larks have shown short-term positive response to fire across several studies (Earnst and others, 2009; Knick and others, 2005; Bock and Block, 2005). The relatively high number of Loggerhead Shrikes we observed in burned areas was intriguing, because other work has found that fire can severely compromise Loggerhead Shrike abundance and nesting success (Humple and Holmes, 2006). We suspect that in the Mojave and Sonoran Desert, shrikes may not necessarily be limited by fire, as long as a limited number of trees remain standing that provide nesting substrate and adequate hunting perches.

The time required for xeroriparian woodland to recover to pre-fire conditions is not well known. Alford and others (2005) speculated that burned Arizona upland habitats north of Phoenix would require 28 years to equal vegetative cover found in adjacent, unburned habitat, but they did not address the structure and composition of this cover, Furthermore, due to precipitation differences and slower growth rate, King Valley's xeroriparian woodlands would be expected to take a much longer period to recover. Using known-age paloverde trees near Tucson, Bowers and Turner (2002) used basal circumference to extrapolate age. Applying crude extrapolation and the expectation of a slower growing rate in the King Valley than in Tucson, basal circumferences of paloverdes, mesquites, and ironwoods at unburned control points suggests that many of the trees lost in the King Valley fire were well over 100 years in age. Therefore, we might expect long-term consequences ( $>25$ years) to the structure of breeding and migrant bird communities following fires in the Mojave and Sonoran Desert ecosystems. Other vegetation dynamics in the post-fire environments likely would attenuate the recovery to the pre-fire composition and structure of this diverse habitat type (Esque and others, 2013). Knick and others (2005) cautioned against over-reliance on short-term comparisons to gauge fire's impact on the avian community, and future surveys of this burn occurring in five or 10-year cycles would more fully evaluate the short- and long-term effects of fire on desert bird communities.

\section{Acknowledgments}

We are grateful for funding provided by the Arizona Bird Conservation Initiative, the U.S. Geological Survey Ecosystem and Health Mission Areas, and the U.S. Fish and Wildlife Service via the Landscape Conservation Cooperative system. In particular, we thank Pattie Bright, George Lerom, and David Lytle for their continued support of our research. Leonard Warren, Caanan Cowles, Rob Klotz, Colin Woolley, Emily Strelow, Paul Taille, Andrew Tillinghast, Cassidy Grattan, Liz Donadio, and Alex Wang conducted point count surveys in 2009 and 2010. Lindsay Smythe and the Kofa National Wildlife Refuge assisted with housing and nest monitoring in 2009 and 2010.

\section{References Cited}

Abella, S.R., 2009, Post-fire plant recovery in the Mojave and Sonoran Deserts of western North

America: Journal of Arid Environments, v. 73, no. 8, p. 699-707.

Alford, E.J., Brock, J.H., Gottfried, G.J., 2005, The effects of fire on Sonoran Desert plant communities: U.S. Department of Agriculture Forest Service Proceedings, RMRS-P-36, p. 451-454. 
Beason, R.C., 1995, Horned Lark (Eremophila alpestris), in Poole, A., ed., The birds of North America: Ithaca, New York, Cornell Lab of Ornithology, accessed December 8, 2015, at http://bna.birds.cornell.edu/bna/species/195.

Bock, C.E., and Block, W.M., 2005, Fire and birds in the southwestern United States, in Saab,V. and Powell, H.D.W., eds., Fire and avian ecology in North America: Camarillo, California, Cooper Ornithological Society, Studies in Avian Biology, no. 30, p. 1-13.

Bowers, J.E., and Turner, R.M., 2002, The influence of climatic variability on local population dynamics of Cercidium microphyllum (foothill paloverde): Oecologia, v. 130, p. 105-113.

Brooks, M.L., and Matchett, J.R., 2006, Spatial and temporal patterns of wildfires in the Mojave Desert, 1980-2004: Journal of Arid Environments, v. 67, p. 148-164.

Buckland, S.T., Anderson, D.R., Burnham, K.P., Laake, J.L., Borchers, D.L., Thomas, L., 2001, Introduction to distance sampling: Oxford, United Kingdom, Oxford University Press, 414 p.

Bukowski, B.E. and Baker, W.L., 2013, Historical fire regimes, reconstructed from land-survey data, led to complexity and fluctuation in sagebrush landscapes: Ecological Applications, v. 23, no. 3, p. 546-564.

Earnst, S.L., Newsome, H.L., LaFramboise, W.L., LaFramboise, N., 2009, Avian response to wildfire in interior Columbia Basin shrubsteppe: The Condor, v. 111, no. 2, p. 370-376.

Elzinga, C.L., Salzer, D.W., and Willoughby, J.W., 1998, Measuring and monitoring plant populations: U.S. Bureau of Land Management, Technical Reference 1730-1, BLM/RS/ST-98/005+1730, 477 p.

Esque, T.C., Webb, R.H., Wallace, C.S.A., van Riper, C., III, McCreedy, C., and Smythe, L., 2013, Desert fires fueled by native annual forbs-Effects of fire on communities of plants and birds in the Lower Sonoran Desert of Arizona: The Southwestern Naturalist, v. 58, no. 2, p. 223-233.

Humphrey, R.R., 1949, Fire as a means of controlling velvet mesquite, burroweed, and cholla on southern Arizona ranges: Journal of Range Management, v. 2, no. 4, p. 175-182.

Humple, D.L., and Holmes, A.L., 2006, Effects of a fire on a breeding population of Loggerhead Shrikes in sagebrush steppe habitat: Journal of Field Ornithology, v. 77, no. 1, p. 21-28.

Knick, S.T., Holmes, A.L., and Miller, R.F., 2005, The role of fire in structuring sagebrush habitats and communities, in Saab, V., and Powell, H.D.W., eds., Fire and avian ecology in North America: Camarillo, California, Cooper Ornithological Society, Studies in Avian Biology, no. 30, p. 1-13.

McCreedy, C., 2010, Birds of Sonoran desert Xeric thorn woodlands-Patterns of bird species composition, richness, abundance, and nest survivorship, 2003-2010: Petaluma, California, PRBO Conservation Science, PRBO Contribution No. 1861.

McLaughlin, S.P., and Bowers, J., 1982, Effects of fire on a Sonoran Desert plant community: Ecology, v. 63, p. 246-248.

Mueller-Dombois, D., and Ellenberg, H., 1974, Aims and methods of vegetation ecology: New York, John Wiley and Sons, 547 p.

Ralph, C.J., Geupel, G.R., Pyle, P., Martin, T.E., and DeSante, D.F., 1993, Field methods for monitoring landbirds: Albany, California, U.S. Department of Agriculture, Forest Service, Pacific Southwest Research Station, General Technical Publication PSW-GTR-144-www, 41 p., http://www.fs.fed.us/psw/publications/documents/psw_gtr144/psw_gtr144.pdf.

Ralph, C.J., Droege, S., and Sauer, J.R., eds., 1995, Monitoring bird populations by point counts: Albany, California, U.S. Department of Agriculture, Forest Service, Pacific Southwest Research Station, General Technical Report PSW-GTR-149, 187 p., http://www.fs.fed.us/psw/publications/documents/psw_gtr149/psw_gtr149.pdf.

Reynolds, R.T., Scott, J.M., and Nussbaum, R.A., 1980, A variable circular plot method for estimating bird numbers: Condor, v. 82, p. 309-313. 
Russell, S.M., and Monson, G., 1998, The birds of Sonora: Tucson, Arizona, University of Arizona Press, 360 p.

Saab, V.A., and Powell, H.D.W., 2005, Fire and avian ecology in North America-Process influencing pattern, in Saab, V., and Powell, H.D.W., eds., Fire and avian ecology in North America: Camarillo, California, Cooper Ornithological Society, Studies in Avian Biology no. 30, p. 1-13.

Yosef, R., 1996, Loggerhead Shrike (Lanius ludovicianus), in Poole, A., ed., The birds of North America: Ithaca, New York, Cornell Lab of Ornithology, accessed December 8, 2015, at http://bna.birds.cornell.edu/bna/species/231. 